\title{
The Maillard reaction and pet food processing: effects on nutritive value and pet health
}

\author{
Charlotte van Rooijen ${ }^{1}$, Guido Bosch ${ }^{1 *}$, Antonius F. B. van der Poel ${ }^{1}$, Peter A. Wierenga ${ }^{2}$, \\ Lucille Alexander ${ }^{3}$ and Wouter H. Hendriks ${ }^{1,4}$ \\ ${ }^{1}$ Animal Nutrition Group, Wageningen University, PO Box 338, 6700 AH Wageningen, The Netherlands \\ ${ }^{2}$ Laboratory of Food Chemistry, Wageningen University, PO Box 8129, 6700 EV Wageningen, The Netherlands \\ ${ }^{3}$ Waltham Centre for Pet Nutrition, Freeby Lane, Waltham-on-the-Wolds, Melton Mowbray, Leicestershire LE14 4RT, UK \\ ${ }^{4}$ Division of Nutrition, Faculty of Veterinary Medicine, Utrecht University, PO Box 80152, 3508 TD Utrecht, The Netherlands
}

\begin{abstract}
The Maillard reaction, which can occur during heat processing of pet foods or ingredients, is known to reduce the bioavailability of essential amino acids such as lysine due to the formation of early and advanced Maillard reaction products (MRP) that are unavailable for utilisation by the body. Determination of the difference between total and reactive lysine by chemical methods provides an indication of the amount of early MRP present in foods, feeds and ingredients. Previous research reported that the difference between total and reactive lysine in pet foods can be up to $61.8 \%$, and foods for growing dogs may be at risk of supplying less lysine than the animal may require. The endogenous analogues of advanced MRP, advanced glycation endproducts, have been associated with age-related diseases in humans, such as diabetes and impaired renal function. It is unknown to what extent advanced MRP are present in pet foods, and if dietary MRP can be associated with the development of diseases such as diabetes and impaired renal function in pet animals. Avoidance of ingredients with high levels of MRP and processing conditions known to favour the Maillard reaction may be useful strategies to prevent the formation of MRP in manufactured pet food. Future work should further focus on understanding the effects of ingredient choice and processing conditions on the formation of early and advanced MRP, and possible effects on animal health.
\end{abstract}

Key words: Extrusion: Advanced glycation endproducts: Reactive lysine: Dogs: Cats

\section{Introduction}

The majority of pet dogs and cats in the developed world are fed processed commercial pet foods throughout their lives ${ }^{(1)}$. These foods are formulated and manufactured to support the pets' nutritional needs, health and vitality. During the manufacturing of most commercial pet foods, thermal treatments are used to improve the safety and nutritive properties of the foods ${ }^{(2)}$. These thermal treatments, including pre-conditioning, extrusion cooking, retorting and pelleting, can improve the digestibility of protein through denaturation and starch by gelatinisation. Moreover, vegetable ingredients such as legumes and cereals may contain anti-nutritional components (for example, trypsin inhibitors, lectins) that are inactivated by thermal treatments ${ }^{(3)}$. Safety and shelf-life are improved by thermal destruction of viable spores and any bacterial contamination.
Besides the above-mentioned beneficial effects, thermal treatments can also negatively influence protein quality due to crosslinking, racemisation, oxidation of sulfurcontaining amino acids, and the involvement of amino acids in the Maillard reaction ${ }^{(4,5)}$. The latter reaction is an important chemical reaction for food manufacturers as it contributes to desired flavour, colour and antioxidative properties in many foods ${ }^{(6-8)}$. However, the Maillard reaction also has unfavourable consequences such as the loss of bioavailable essential amino acids ${ }^{(9,10)}$. During the Maillard reaction, a reducing sugar binds to a free reactive amino group of an amino acid. In food proteins, the reactive $\varepsilon$-amino group of lysine is the most important source of reactive amino groups ${ }^{(10,11)}$. Previous research has indicated that up to $61 \cdot 8 \%$ of the lysine in pet foods contains a bound $\varepsilon$-amino group, probably due to its involvement in the Maillard reaction ${ }^{(12,13)}$. This complex, also referred to as early Maillard reaction products (MRP), may be

Abbreviations: AGE, advanced glycation endproducts; CML, $N^{\varepsilon}$-(carboxymethyl)lysine; DNP, dinitrophenol; FDNB, fluorodinitrobenzene; HMF, hydroxymethylfurfural; ME, metabolisable energy; MRP, Maillard reaction products; NRC, National Research Council; OMIU, O-methylisourea; OPA, ortho-phthaldialdehyde.

*Corresponding author: Dr Guido Bosch, fax +31 317 484260, email guido.bosch@wur.nl 
absorbed from the gastrointestinal tract but cannot be utilised by the animal ${ }^{(10,14,15)}$. As lysine is the first or second limiting essential amino acid in commercial foods for cats and $\operatorname{dogs}^{(16)}$, a reduced utilisation results in a reduced nutritive value of the food. In addition to the loss of essential amino acids, advanced MRP may have an influence on health. Some of these MRP are also endogenously formed, i.e. formed in the body, and have been associated with age-related diseases in humans and dogs ${ }^{(17)}$.

As commercially prepared pet foods are often routinely fed throughout the entire life of domestic cats and dogs, it is important to understand the factors that influence the availability of essential amino acids such as lysine and the formation of potentially bioactive MRP. The purpose of this review is to present an overview of the effect of the Maillard reaction on the nutritive value of pet foods in relation to the requirements of the animal. In addition, the potential health implications of MRP for dogs and cats are discussed. Factors influencing the formation of MRP in pet foods, including recipe ingredients and processing techniques used during pet food manufacture, will be presented in the context to minimising the formation of early and advanced MRP in complex matrices such as pet foods.

\section{The Maillard reaction}

The Maillard reaction is a non-enzymic browning and flavouring reaction that can occur during the processing and storage of foods ${ }^{(18)}$. Often free amino acids or amino acids in peptides and proteins are involved in the Maillard reaction. Free amino acids contain an $\alpha$-amino $\left(-\mathrm{NH}_{2}\right)$ group as well as a functional side chain that varies between amino acids and can react during the Maillard reaction ${ }^{(10)}$ In peptides and proteins, amino acids form (poly)peptide chains through a polymerisation reaction, whereby the $\alpha$-amino group links to an $\alpha$-carboxyl group and becomes unavailable for the Maillard reaction. As a result, in peptides and proteins only the side chains of amino acids are reactive in the Maillard reaction. In a free as well as a protein-bound form, the $\varepsilon$-amino side chain of lysine is the most susceptible group to the Maillard reaction ${ }^{(7,10,11,19)}$. Side chains of other amino acids, for example the guanidine side group of arginine, and side chains of histidine and tryptophan, are also known to be involved in the Maillard reaction but are less well studied ${ }^{(11,20)}$. Next to free amino acids and proteins, amino lipids and nucleic acids can also be involved in the Maillard reaction.

The Maillard reaction can be divided into early, advanced and final stages (Fig. 1). In the early stage,

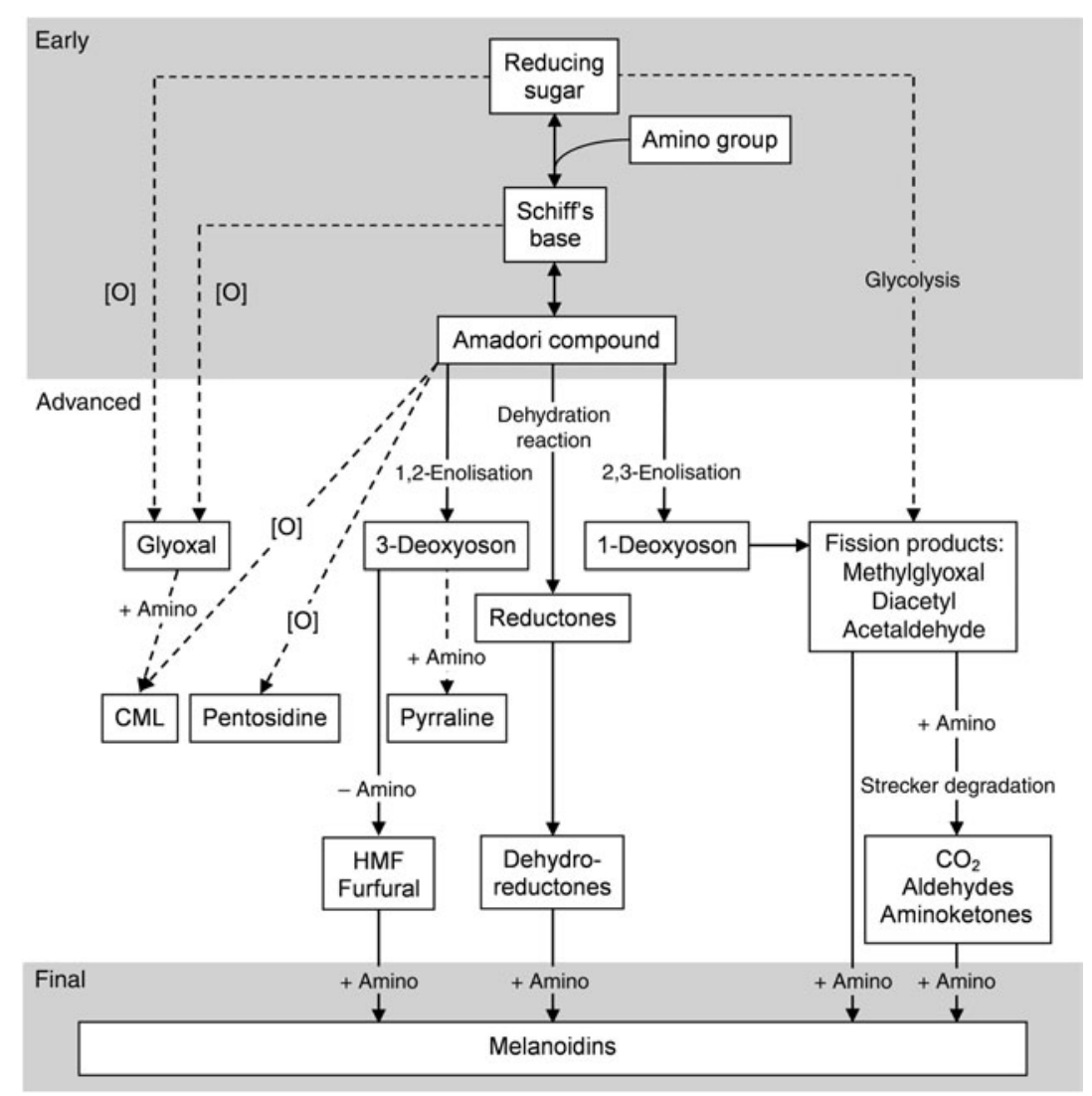

Fig. 1. Scheme of the early, advanced and final Maillard reaction pathways and formation of Maillard reaction products and melanoidins (modified after Hodge ${ }^{(5)}$ ). [O], oxidation; CML, $N^{\varepsilon}$-(carboxymethyl)lysine; HMF, hydroxymethylfurfural. 
the carbonyl group of a reducing sugar reacts through a condensation reaction with the $\varepsilon$-amino group of lysine, resulting in the formation of a reversible Schiff's base. The Schiff's base can undergo an Amadori rearrangement resulting in the formation of the Amadori compound $\varepsilon-N$-deoxyketosyllysine ${ }^{(21)}$. It seems that the Amadori rearrangement can be reversible under certain conditions; however, the mechanism is not fully understood and it is unknown whether it is of quantitative relevance in the Maillard reaction ${ }^{(22)}$. In the advanced stage of the Maillard reaction, the Amadori compound can react further through several pathways, including rearrangement, condensation, oxidation and dehydration (and hydration) reactions, which lead to the formation of advanced MRP. Several $\alpha$-oxoaldehydes including glyoxal, 1-,3-deoxyglucosones and fission products such as methylglyoxal are formed, either by non-oxidative rearrangements or by oxidation and glycolysation. These compounds are high in oxidative potential and, therefore, tend to be pro-oxidative ${ }^{(23-26)}$. $\alpha$-Oxoaldehydes and $\varepsilon$ - $N$-deoxyketosyllysine react with proteins (or lipids) to generate oxidants such as $N^{\varepsilon}$-(carboxymethyl)lysine (CML) or crosslink-forming endproducts such as pentosidine. Other advanced MRP derived from these precursors include pyrraline and hydroxymethylfurfural (HMF). These advanced MRP are the most common compounds and are used as markers to indicate the extent of the Maillard reaction in foods ${ }^{(27)}$. Amadori compounds that undergo a dehydration reaction result in reductones and dehydroreductones. In addition, the Strecker degradation converts fission products with an amino group into aldehydes, aminoketones and $\mathrm{CO}_{2}$. In the final stage, MRP further react with free amino groups to produce melanoidins which are responsible for the characteristic brown colour of heated foods ${ }^{(10,28)}$. Increased antioxidant activity is observed during the formation of brown colouring ${ }^{(24,28)}$, which can be mainly attributed to the reductones and dehydroreductones that can act as antioxidants in their reduced state ${ }^{(29)}$.

\section{Determining Maillard reaction products in processed foods and ingredients}

Several methods have been developed to quantify MRP in processed foods and ingredients. Total lysine content of foods and ingredients is usually determined using traditional amino acid analysis. Proteins are heated in concentrated acid (for example, $6 \mathrm{M}-\mathrm{HCl}$ ) at $110^{\circ} \mathrm{C}$ for $24 \mathrm{~h}$, hydrolysing the peptide bonds and resulting in free amino acids that can be quantified using chromatographic separation. However, total lysine may not be suitable for quantifying nutritional available lysine in processed foods, feeds and ingredients as the early and some advanced MRP can revert back to lysine during the acid hydrolysis step ${ }^{(11,30-32)}$. Bioavailable lysine is defined as the reactive lysine that is digested, absorbed and potentially can be utilised for metabolism. Bioavailable lysine can be determined by either an animal growth assay where the ability of an animal to deposit protein or amino acids from a test diet is measured, or the true ileal amino acid digestibility assay ${ }^{(14,31)}$. These methods are the most accurate but costly and time consuming. Alternative methods based on a reaction of chemical compounds with the free $\varepsilon$-amino group of lysine have been developed to measure reactive lysine in foods, feeds and ingredients. The most well-known method, and considered to be the reference method for determination of reactive lysine, was developed by Carpenter ${ }^{(33)}$ and revised by Booth ${ }^{(34)}$. Free amino groups of lysine in protein react with fluorodinitrobenzene (FDNB) to form the acid-resistant yellow compound dinitrophenol (DNP)-lysine. After hydrolysis of the protein, the $\alpha$-DNP-amino acids are removed by ether extraction. The remaining ether-insoluble $\varepsilon$-DNP-lysine is detected spectrophotometrically. Variations on the FDNB-reactive lysine method have been developed. In the 'Silcock' method, reactive lysine in samples is determined as the difference between total lysine before the reaction with FDNB and the residual lysine present after the reaction ${ }^{(35)}$. Determination of $\varepsilon$-DNP-lysine by HPLC results in higher values compared with the original method of Carpenter ${ }^{(33)}$, possibly due to compounds formed during hydrolysis that interfere with the spectrophotometric determination of $\varepsilon$-DNP-lysine ${ }^{(36)}$. Trinitrobenzenesulfonic acid and sodium borohydride have also been used to form acid-stable complexes with the free $\varepsilon$-amino group of lysine; the formed complexes are measured after hydrolysis using a spectrophotometer or amino acid analyser ${ }^{(37,38)}$. The 'dye binding lysine' method of Hurrell et al. ${ }^{(39)}$ is based on the difference between measurement of unmodified amino acids with Acid Orange 12 and after the $\varepsilon$-amino group of lysine has been blocked through a reaction with propionic anhydride; reactive lysine content is then calculated from the difference ${ }^{(39)}$. Another binding agent is ortho-phthaldialdehyde (OPA), which forms a fluorescent reaction product with the free amino groups in proteins ${ }^{(40)}$. The fluorescent intensity measured is corrected for the contribution of N-terminal amino groups to determine the reactive lysine content. In the above-mentioned methods, the chemical compounds bind to both the $\alpha$ - and $\varepsilon$-amino group of lysine and are, therefore, not suitable for accurate determination when free or synthetic lysine is present ${ }^{(31)}$. The guanidination method uses $O$-methylisourea (OMIU) as a reagent which is able to bind to only free $\varepsilon$-amino groups, converting lysine into homoarginine ${ }^{(41)}$. Homoarginine is acid stable ${ }^{(42)}$ and, after acid hydrolysis via traditional amino acid analysis, allows for the accurate determination of the reactive lysine contents of foods, feeds and ingredients. A good correlation has been demonstrated between the FNDB- and OMIU-reactive lysine methods for a range of animal feedstuffs ( $r$ 0.996) and breakfast cereals ( $r$ 0.985), indicating that results obtained by the two methods are comparable ${ }^{(31)}$. According to Rutherfurd \& Moughan ${ }^{(31)}$, 
the guanidination method is the most preferred method to analyse reactive lysine in processed foods and ingredients.

In terms of terminology, the present review will refer to total lysine as lysine molecules with a free $\varepsilon$-amino group and lysine that reverts back to lysine after standard acid hydrolysis. Reactive lysine is undamaged lysine that has a reactive $\varepsilon$-amino side chain. The difference between total and reactive lysine, therefore, is a measure of the lysine that reverts back to lysine after acid hydrolysis and includes lysine involved in the early Maillard reaction. Most lysine that has reacted to yield advanced Maillard products does not revert back to lysine during acid hydrolysis and as such the difference between total and reactive lysine is, therefore, not equal to the lysine that has undergone the Maillard reaction. It is, however, often used as an indication of heat damage of processed foods, feeds and ingredients $^{(4,11)}$.

To be able to measure MRP in foods, feeds and ingredients, other chemical markers can be analysed. Furosine ( $\varepsilon-N$-(furoyl-methyl)-L-lysine) is an amino acid formed during acid hydrolysis of the Amadori compound fructoselysine and is produced by reaction of the $\varepsilon$-amino groups of lysine with glucose. As such, furosine is a specific chemical marker of the Amadori compound generated during the early Maillard reaction ${ }^{(27,43)}$. In the advanced stage, the extent of the Maillard reaction can be measured in several ways. The colour formation during this stage can be measured by absorbance at $420 \mathrm{~nm}$. In addition, dehydration and fission reactions form fluorescent compounds that can be measured by fluorescence spectrophotometry at $347 \mathrm{~nm}$ excitation and $415 \mathrm{~nm}$ emission ${ }^{(44)}$. Specific markers of the advanced stage such as HMF and CML are often analysed by ultra-performance liquid chromatography or HPLC, sometimes combined with MS ${ }^{(45)}$.

From a practical point of view, procedures that can rapidly provide an indication of the occurrence of the Maillard reaction due to heat processing of foods, feeds or ingredients are necessary. Besides the furosine, colour and fluorescence methods, the total or reactive lysine: crude protein ratio seems to be a relatively rapid method to estimate heat damage as the concentration of lysine, but not the concentration of crude protein, reduces if samples are extensively heat processed ${ }^{(46,47)}$. This method is, however, mainly tested in distillers dried grains with solubles (DDGS) and soyabean meal. An increase of dark colour in DDGS was related to an increase in acid-detergent fibre $(r 0.62 ; P<0.10)$ and acid-detergent insoluble $\mathrm{N}(r \quad 0.79 ; P<0.01)$ during heat processing, indicating that these components can be indicators of the Maillard reaction especially in fibrous feeds or ingredients ${ }^{(48,49)}$. Near-IR reflectance spectroscopy might be a future method to determine reactive lysine in foods, feeds and ingredients; however, data are limited.

\section{The Maillard reaction in model systems}

The Maillard reaction has been extensively studied using pure compounds as well as heat-treated food systems ${ }^{(10,11,50)}$. Studies of pure compounds in model systems indicate that the type of reactions and the extent to which they occur depend on several reaction conditions. In terms of amino acid type, lysine had the highest reactivity among twelve investigated amino acids (aspartic acid, glutamic acid, alanine, leucine, isoleucine, valine, proline, serine, cysteine, phenylalanine, arginine and lysine) when heated with reducing sugars at $100^{\circ} \mathrm{C}$ for $3 \mathrm{~h}$ as measured by the formation of MRP with absorbance at $420 \mathrm{~nm}^{(19)}$. As the heating time was increased to $12 \mathrm{~h}$, the colour intensity of the MRP from lysine became two to three times higher than that of the other amino acids ${ }^{(19)}$. In terms of reducing sugar type, glucose has been reported to be the most reactive reducing sugar when heated at $60^{\circ} \mathrm{C}$ in the presence of casein; OPA-reactive lysine content decreased by about $60 \%$ within $10 \mathrm{~h}$, followed by maltose $(15 \mathrm{~h})$, lactose $(20 \mathrm{~h})$ and fructose $(35 \mathrm{~h})^{(51)}$. Brands et $\mathrm{al}^{(52)}$, however, observed contradictory results when casein was heated at $120^{\circ} \mathrm{C}$ for $90 \mathrm{~min}$ in the presence of glucose or fructose, with fructose being more reactive than glucose. After 60 min of heating, both reducing sugars induced an OPA-reactive lysine reduction of about $60 \%$. In a model system consisting of soyabean protein concentrate, glucose and microcrystalline cellulose, heated at $95^{\circ} \mathrm{C}$ for $75 \mathrm{~min}$ FDNB-reactive lysine content was reduced by $31.9 \%{ }^{(53)}$. OPA-reactive lysine reduction appeared to be faster with increasing temperatures from 37 to $60^{\circ} \mathrm{C}^{(51)}$. Increasing the $\mathrm{pH}$ from 4 to 12 at a temperature of $100^{\circ} \mathrm{C}$ decreased total lysine content by up to $50 \%$ after $2 \mathrm{~h}$ in the presence of fructose ${ }^{(54)}$. In addition, lowering the water content $(\mathrm{w} / \mathrm{w})$ of a sugar-amino acid model system from 100 to $20 \%$ increased colour formation ${ }^{(55)}$. Based on these data, it appears that in model systems the type of amino acid and the type of reducing sugar influence the extent of the Maillard reaction. In addition, increasing heating temperature and time, $\mathrm{pH}$ level and decreasing water content increase the reaction of lysine.

\section{Effects of the Maillard reaction on the nutritive value of pet foods}

As described above, the early MRP of lysine may be partly absorbed but has no nutritional value ${ }^{(14,32,56,57)}$. This impaired utilisation of lysine that has undergone the Maillard reaction was recently confirmed in a kitten growth study ${ }^{(58,59)}$. Kittens fed an experimental diet including a heated casein-dextrose mixture containing a difference between total and reactive lysine of $32.9 \%$ resulted in a lower growth rate (mean daily gain of $2.7 \mathrm{~g}$ ) compared with kittens fed a control diet including unheated casein containing a difference between total and reactive lysine of $0.4 \%$ (mean daily gain of $14 \cdot 9 \mathrm{~g}$ ). 
Adding $4 \cdot 0,5 \cdot 5$ and $7 \cdot 0 \mathrm{~g}$ of synthetic lysine to the heated casein diet increased mean daily gain of the kittens to $5 \cdot 4,11 \cdot 2$ and $20 \cdot 1 \mathrm{~g}$, respectively. This study clearly indicates that the bioavailability of lysine can be significantly impaired by heating. Quantification of reactive lysine is therefore important for the evaluation of the nutritive value of pet foods.

Bioavailability of nutrients, including lysine, is taken into account in the nutritional recommendations for the formulation of complete pet foods. The recommended allowances of lysine for dogs at maintenance based on scientific principles presented by the National Research Council (NRC) ${ }^{(16)}$ and the European Pet Food Industry Federation (FEDIAF) ${ }^{(60)}$ include a bioavailability factor of 0.80 and 0.67 , respectively. The Association of American Feed Control Officials (AAFCO) ${ }^{(61)}$ is a regulatory organisation that sets standards for the quality and safety of animal feed and pet food in the USA. AAFCO provides higher recommended lysine allowances compared with NRC, i.e. $6.3 v .3 .5 \mathrm{~g} / \mathrm{kg} \mathrm{DM}$, including a bioavailability factor of 0.44 when calculated using the NRC minimal requirement of $2 \cdot 8 \mathrm{~g} / \mathrm{kg} \mathrm{DM}^{(16)}$. The fraction of the lysine in foods that is actually bioavailable depends on the extent of the fraction of lysine that has undergone the Maillard reaction and the ileal digestibility of the reactive lysine. The difference between total and reactive lysine of commercially produced canned and dry dog and cat foods can be considerable, with values reported of up to $61 \cdot 8 \%^{(12,13,62)}$. Furthermore, apparent ileal crude protein digestibility has been shown to be highly variable among $141 \mathrm{dog}$ foods, with values ranging from $51.1 \%$ up to $90.5 \%$ and a mean digestibility of $73.5 \%{ }^{(63)}$. As variability in amino acid digestibility can be expected to be similar to crude protein digestibility, these results indicate that lysine digestibility is likely to be highly variable as well. Data on ileal reactive and total lysine digestibility in dogs are scarce. However, recently Hendriks et al. ${ }^{(64)}$ reported standardised ileal OMIU-reactive lysine digestibility values in dogs fed five commercial dry dog foods containing varying protein contents $(24.4$ to $32.7 \% \mathrm{DM})$ of 79.5 to $93.7 \%$ with a mean of $88.2 \%$. Corresponding standardised ileal total lysine digestibility values of these foods were $64 \cdot 2$ to $87 \cdot 2 \%$, with a mean of $80.0 \%$. In another study involving $\operatorname{dogs}{ }^{(65)}$, the apparent ileal total lysine digestibility of a commercial dry dog food was reported to be $83.6 \%$. The bioavailable reactive lysine, i.e. standardised ileal digestible OMIU-reactive lysine, contents of the five commercial foods ${ }^{(64)}$ met the minimal lysine requirement of $2 \cdot 8 \mathrm{~g} / \mathrm{kg}$ DM for dogs at maintenance ${ }^{(16)}$ when a dietary energy density of $16.7 \mathrm{MJ}$ ( $4000 \mathrm{kcal}$ ) metabolisable energy (ME) $/ \mathrm{kg}$ is assumed (Fig. 2). The OMIU-reactive and total lysine contents of twenty-seven commercial maintenance foods for $\operatorname{dogs}^{(12,62)}$ are reported in Fig. 3. These foods varied considerably in terms of differences between total and reactive lysine, with values up to $56.0 \%$ and an overall mean of $15.4 \%$. Assuming a dietary energy density of $16.7 \mathrm{MJ}$ ( $4000 \mathrm{kcal}) \mathrm{ME} / \mathrm{kg}$, these foods were well above the minimal lysine requirement. The two foods with the lowest OMIU-reactive lysine contents would have been deficient in lysine if their ileal reactive lysine digestibilities were 51.7 and $46.9 \%$, which may be considered unlikely. The OMIU-reactive and total lysine contents of fourteen commercial growth foods for $\operatorname{dogs}^{(12)}$ are reported in Fig. 4. For growing dogs dietary total lysine contents were all above the recommended allowance as set by the $\mathrm{NRC}^{(16)}$ (Fig. 4). The OMIU-reactive lysine contents of two foods, however, were below the minimal total lysine requirements of $7 \mathrm{~g} / \mathrm{kg}$ DM for growing dogs between 4 and 14 weeks of age ${ }^{(16)}$, assuming a dietary energy density of $16.7 \mathrm{MJ}$ ( $4000 \mathrm{kcal}) \mathrm{ME} / \mathrm{kg}$. If these foods for

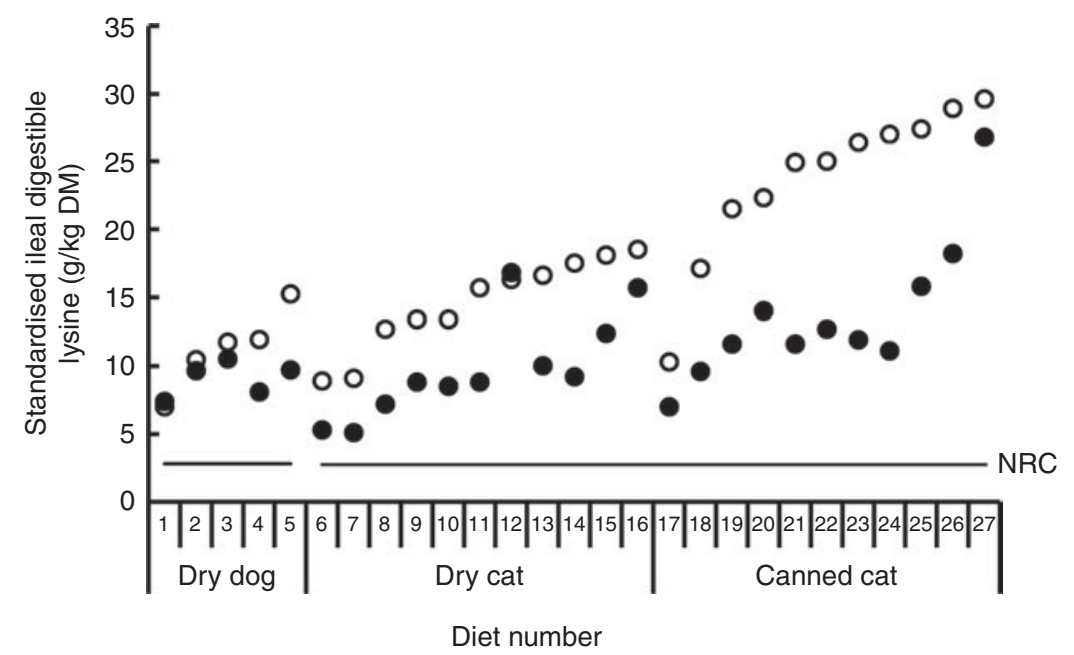

Fig. 2. Standardised ileal digestible total lysine $(O)$ and standardised ileal digestible $O$-methylisourea (OMIU)-reactive lysine $(\bullet)$ contents for five commercial dry maintenance foods for dogs using ileally cannulated dogs ${ }^{(64)}$ and twenty-two commercial maintenance (SM Rutherfurd, personal communication) foods for cats using the rat as the model animal ${ }^{(13,31)}$. Horizontal solid lines indicate the minimal lysine requirement for maintenance for dogs and cats presented by the National Research Council (NRC) ${ }^{(16)}$, being, respectively, 2.8 and $2.7 \mathrm{~g} / \mathrm{kg} \mathrm{DM}$, assuming a dietary energy density of $16.7 \mathrm{MJ}(4000 \mathrm{kcal}) \mathrm{metabolisable} \mathrm{energy/kg.}$ 


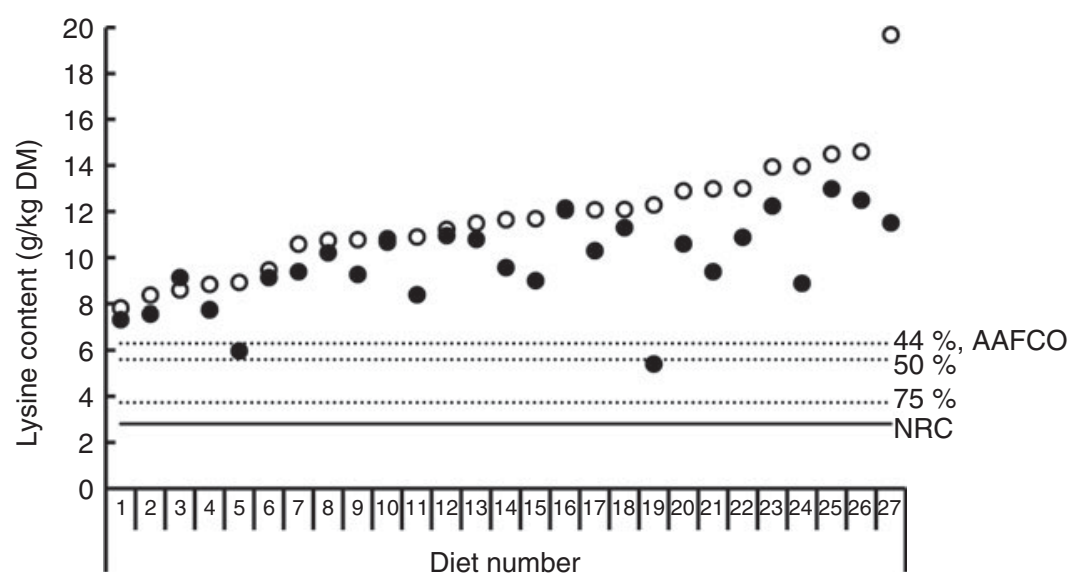

Fig. 3. Total lysine $(O)$ and $O$-methylisourea (OMIU)-reactive lysine $(\bullet)$ contents for twenty-seven commercial dry maintenance foods for dogs ${ }^{(12,62)}$ (reanalysis of original data of Williams et al. $\left.{ }^{(12)}\right)$. The horizontal solid line indicates the minimal lysine requirement for maintenance for dogs presented by the National Research Council (NRC) ${ }^{(16)}$, being $2.8 \mathrm{~g} / \mathrm{kg} \mathrm{DM}$, assuming a dietary energy density of $16.7 \mathrm{MJ}(4000 \mathrm{kcal})$ metabolisable energy/ $\mathrm{kg}$. Dotted lines indicate bioavailability thresholds of 75 and $50 \%$ for meeting minimal lysine requirements. The recommended lysine allowance for dog maintenance foods of the Association of American Feed Control Officials (AAFCO) ${ }^{(61)}$ equals a dietary lysine bioavailability of $44 \%$.

growing dogs were used as weaning diets, the minimal requirement for growing dogs between 4 and 14 weeks would not be met. No ileal reactive lysine digestibility data are available for growing dogs. Assuming that the ileal reactive lysine digestibility was within the range presented by Hendriks et al. ${ }^{(64)}$ (79.5 to $93.7 \%$ ), three commercial foods would have had reactive lysine contents below the minimal total lysine requirements for 4 - to 14 -week-old growing dogs. It should be noted that growing dogs (and cats) have lower gastric pepsin secretion ${ }^{(66)}$, so digestibility values would probably be lower than those observed in adult dogs. As long as the reactive lysine digestibility for the other eleven foods were above $70.0 \%$, these foods would have met the minimum lysine requirements for 4- to 14-week-old growing dogs. Interpretation of these results should take into account that most studies use commercially available single batch pet foods. Batch variation in ingredients as well as processing conditions (see further in the present review) can result in variation in the difference between total and reactive lysine content between batches of pet foods.

The difference between total and reactive lysine appears to be greater in commercial cat foods than in dog foods. Rutherfurd et $a l^{(13)}$ reported average differences between total and reactive lysine values in canned cat foods ( $n 10)$ of $48.6 \%$ (range $39 \cdot 0-61.8 \%$ ) and in dry cat foods ( $n 10)$ of $41 \cdot 2 \%$ of total lysine (range 20.1-48.7\%) values (Fig. 5). As long as the reactive lysine digestibilities are above $50.0 \%$, these foods will meet the minimum lysine requirements for adult cats ${ }^{(16)}$. Using the rat as model animal, standardised ileal OMIU-reactive lysine digestibility of the canned cat foods ranged from 79.9 to $97 \cdot 1 \%$ with a mean of $88.1 \%$ while for the dry cat foods values ranging from 89.9 to $97.7 \%$ with a mean of $94.8 \%$ were reported $^{(13)}$. These values are higher than a previously reported value of $71.5 \%$ for the apparent ileal total lysine digestibility of a canned cat food using the rat as the model animal ${ }^{(67)}$. The latter is probably due to the difference in method (standardised $v$. apparent) and the presence of early MRP (OMIU-reactive only $v$. OMIU-reactive plus Amadori compounds). Assuming a dietary energy density of $16.7 \mathrm{MJ}$ (4000 kcal) $\mathrm{ME} / \mathrm{kg}^{(16)}$, the approximated ileal digestible OMIU-reactive lysine content of these cat foods was higher than the minimal lysine requirements for maintenance in cats (Fig. 2).

Overall, these data indicate that the difference between total and reactive lysine in commercial dog and cat foods can be considerable, in particular in canned foods. Factors such as ingredients used and processing conditions applied which contribute to the difference between total and

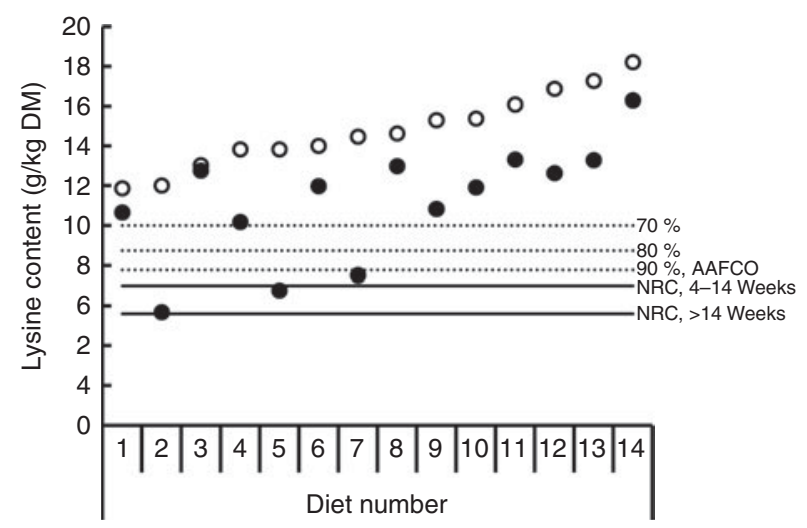

Fig. 4. Total lysine $(O)$ and $O$-methylisourea (OMIU)-reactive lysine (๑) contents for fourteen commercial growth foods for dogs (reanalysis of original data of Williams et al. $\left.{ }^{(12)}\right)$. Horizontal solid lines indicate the minimal lysine requirement for growing dogs between 4 and 14 weeks old and older than 14 weeks presented by the National Research Council (NRC) ${ }^{(16)}$, being, respectively, 7.0 and $5.6 \mathrm{~g} / \mathrm{kg} \mathrm{DM}$, assuming a dietary energy density of $16.7 \mathrm{MJ}(4000 \mathrm{kcal})$ metabolisable energy $/ \mathrm{kg}$. Dotted lines indicate bioavailability thresholds of 90,80 and $70 \%$ for meeting minimal lysine requirements. The recommended lysine allowance for dog maintenance foods of the Association of American Feed Control Officials (AAFCO) $)^{(61)}$ equals a dietary lysine bioavailability of $90 \%$. 


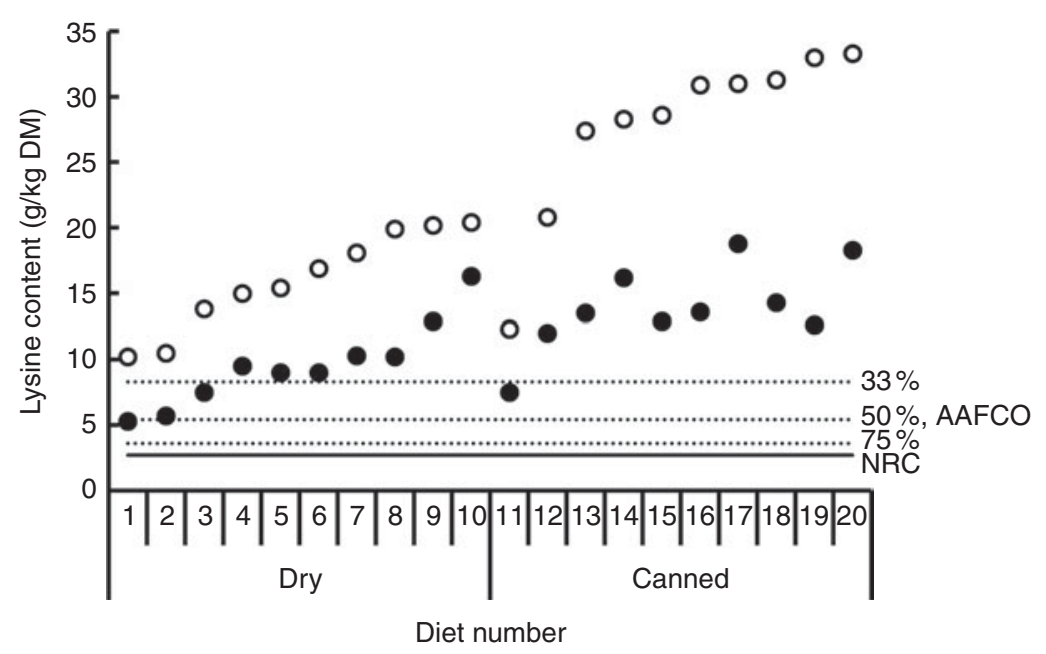

Fig. 5. Total $(\mathrm{O})$ and $\mathrm{O}$-methylisourea (OMIU)-reactive lysine $(\bullet)$ contents of twenty commercial maintenance (SM Rutherfurd, personal communication) foods for cats ${ }^{(13)}$. The horizontal solid line indicates the minimal lysine requirement for maintenance of cats presented by the National Research Council (NRC) ${ }^{(16)}$, being $2.7 \mathrm{~g} / \mathrm{kg} \mathrm{DM}$, assuming a dietary energy density of $16.7 \mathrm{MJ}(4000 \mathrm{kcal})$ metabolisable energy $/ \mathrm{kg}$. Dotted lines indicate bioavailability thresholds of 75 and $50 \%$ for meeting minimal lysine requirements. The recommended lysine allowance for dog maintenance foods of the Association of American Feed Control Officials $(\text { AAFCO) })^{(61)}$ equals a dietary lysine bioavailability of $33 \%$.

reactive lysine in pet foods are described below. The standardised ileal digestibility of reactive lysine in analysed pet foods appears to be $80.0 \%$ or higher. However, the number of pet foods evaluated is limited. In particular, the lysine supply of certain commercial foods consumed by growing dogs, and possibly also growing cats, can be compromised due to differences between total and reactive lysine. Further prospective studies are required to identify the effects of early MRP during growth.

\section{Effects of glycated Maillard reaction products on health}

The Maillard reaction does not only occur during heat treatment of pure compounds or food systems but is also a naturally occurring process in body tissues. Biological interest in the endogenously occurring Maillard reaction was initiated during the late 1960s with the identification of non-enzymically glycated $\mathrm{Hb}$ in the blood of diabetic patients ${ }^{(68,69)}$. During normal metabolism at homeostatic concentrations of glucose, endogenous proteins can be glycated resulting in advanced glycation endproducts $(\mathrm{AGE})^{(70,71)}$. A large number of AGE have been identified in vivo including CML, HMF, pentosidine and pyrraline. These AGE are the most widely studied and used as biomarkers for in vivo formation of $\mathrm{AGE}^{(70,72)}$.

AGE have a variety of predominantly adverse biological effects. AGE can be pro-oxidants that can modify physicochemical properties of proteins by covalently crosslinking to proteins and thereby modifying structural and functional properties of the proteins. As the crosslinks of AGE and proteins are resistant to degradation, turnover rate is delayed and tissue repair hindered ${ }^{(73-75)}$. This results in accumulation of AGE in tissues with amounts depending on the turnover rate of the protein. As a result, proteins with a slow turnover such as collagens in connective tissue, eye lenses and nerve myelin are sensitive to AGE accumulation $^{(76,77)}$. Due to the modified physico-chemical properties of tissue proteins, AGE can become pathogenic. This could, for example, lead to stiffening of collagen fibres in the arterial wall leading to vascular complications $^{(78)}$. Next to physico-chemical protein modifications, AGE can elicit cell-mediated responses through interaction with several cellular AGE receptors and induce cellular signalling, activation of transcription factors and subsequent gene expression. These receptors are expressed on a wide range of cells including smooth muscle cells, monocytes, macrophages, endothelial cells, podocytes, astrocytes and microglia ${ }^{(79)}$. The best-characterised receptor is RAGE ('receptor for AGE'), which belongs to the Ig superfamily and is capable of interacting with a broad spectrum of ligands, including AGE. Binding of an AGE to the receptor leads to activation of transcription factor NF- $\kappa \mathrm{B}$ which in turn can lead to oxidative stress, vasoconstriction and inflammatory responses ${ }^{(80,81)}$. Under certain pathological conditions, such as hyperglycaemia or oxidative stress in diabetes mellitus, AGE formation can be accelerated. AGE have been, therefore, proposed to contribute to the development of long-term complications of diabetes ${ }^{(79)}$. In addition, AGE may contribute to the pathogenesis of age-related diseases such as atherosclerosis, nephropathy, retinopathy, osteoarthritis and neurodegenerative diseases such as Alzheimer's disease in humans ${ }^{(17,79,82)}$. Age-related diseases such as diabetes and renal, cardiovascular and neurodegenerative diseases are also seen in dogs, showing many similarities to these diseases in humans ${ }^{(83-85)}$. RAGE are reported in $\operatorname{dogs}^{(86)}$, and several studies have been conducted indicating that AGE also accumulate by binding to tissue proteins of ageing and diseased dogs. Comazzi et $a l{ }^{(87)}$ reported higher AGE in plasma from dogs suffering from canine diabetes mellitus compared with control 
animals. In addition, elevated levels of AGE in tissue proteins in dogs were seen during cataract in the canine eye lens ${ }^{(88)}$, osteoarthritis $^{(17)}$, neurodegenerative diseases such as canine cognitive dysfunction syndrome ${ }^{(89)}$, vascular dysfunction $^{(90)}$, atherosclerosis ${ }^{(91)}$, and in skin collagen ${ }^{(92)}$ with increasing age.

As indicated above, AGE formation occurs naturally in the body and defence mechanisms have evolved to protect against the adverse effects of (endogenously) formed AGE. Effects of AGE are avoided or regulated by renal AGE elimination and detoxification, antioxidant systems and suppression of signalling via the AGE receptor AGER1 ${ }^{(75)}$. As in humans, the dietary intake of AGE, such as CML, $\mathrm{HMF}$, pentosidine and pyrraline, formed during the processing of foods potentially provides an additional AGE load to dogs and cats. These dietary components appear to be, at least partially, digestible and transported through the general circulation. A significant correlation $\left(\begin{array}{rl}r & 0.8\end{array}\right)$ between ingested MRP and serum concentrations were observed when comparing the ingestion of a high-MRP diet $v$. a low-MRP diet in human diabetes mellitus patients with or without kidney disease ${ }^{(93)}$. The latter authors reported that about $10 \%$ of the dietary AGE were observed in serum. This supports the idea that dietary MRP contribute to the body's AGE pool ${ }^{(94)}$. As in tissues where the crosslinks of AGE and proteins are resistant to degradation, the majority (about 70\%) of dietary AGE is not available either because the crosslinks are resistant to enzymic hydrolysis, or trypsin digestion is impaired due to the absence of a positive charge on lysine in the intestinal tract $^{(93)}$. To the authors' knowledge, no data are available in the scientific literature on the absorption and excretion of dietary MRP in dogs and cats.

There are large differences in absorption, metabolism and excretion between the different MRP. Advanced MRP such as CML, pyrraline and pentosidine seem to be absorbed by the gut. Ingested dietary CML in rats appeared to be approximately 26.0 to $29.0 \%$ excreted in the urine, and 15.0 to $22.0 \%$ excreted in faeces ${ }^{(95)}$. Approximately $1.7 \%$ of dietary CML accumulated in the circulation, kidney and liver and approximately $50.0 \%$ of the ingested CML was not recovered. This was confirmed in a later study where $31.2 \%$ of ingested dietary CML was excreted in the faeces, $14.4 \%$ in the urine, and $54.4 \%$ left unrecovered in human subjects ${ }^{(96)}$. Whether the unrecovered CML is deposited in organs, degraded by colonic microbiota or metabolised is unknown. Approximately $80 \%$ of dietary pyrraline is absorbed and excreted via the kidneys in humans within $48 \mathrm{~h}^{(97)}$. Urinary pyrraline is almost exclusively of dietary origin, and pyrraline is most probably not metabolised post-absorption. Approximately $2.0 \%$ of dietary pentosidine is recovered in urine in the peptidebound form; however, approximately $60.0 \%$ is recovered in the free form ${ }^{(98)}$. The remainder may have been metabolised into unknown compounds and also excreted in the urine. Oral administration of HMF in rats resulted in rapid absorption. Excretion was primarily via urine, with between 66.3 and $80.0 \%$ of the radioactivity excreted in urine in the first $24 \mathrm{~h}^{(99)}$. In faeces, 8.5-12.2\% was excreted within $48 \mathrm{~h}$. The highest concentration of HMF in organs was observed in the liver and kidneys, the major organs for metabolism and excretion ${ }^{(99)}$. There was no evidence of prolonged accumulation in any other tissues. The MRP that are not absorbed can be metabolised by intestinal microbes ${ }^{(100,101)}$, giving MRP including Amadori products and melanoidins biotic properties ${ }^{(102-104)}$. The majority of the ingested MRP are not bioavailable; most of the absorbed MRP are excreted via the urine, however, some of the dietary MRP may accumulate in body tissues. In addition, it is seen that dietary MRP increase markers associated with an increased risk of type 2 diabetes and CVD in healthy individuals, and dietary MRP promote inflammatory mediators in diabetics, which may lead to tissue injury ${ }^{(75,105,106)}$; restriction of dietary MRP suppressed these effects. In contrast to human foods, there is at present only one study reporting concentrations of early MRP, and no data on the concentrations of advanced MRP in pet foods have been reported. The difference between total and reactive lysine reported in pet foods, and a furosine level of $0.91 \mathrm{mg} / \mathrm{g}$ reported in a dry dog food $^{(107)}$ indicate that at least the early phase of the Maillard reaction has occurred. In addition, there is no information available on the absorption of MRP in the gastrointestinal tract of dogs and cats and the contribution of dietary MRP to the body's AGE pool. At this stage, it can only be hypothesised that the daily intake of thermally processed foods could provide an additional peak load of AGE that may exceed the natural capacity to protect against AGE. In addition, it is unknown whether endogenous AGE formation is stimulated due to a postprandial increase in blood glucose levels. Dry foods for cats and dogs can contain up to $60 \%$ carbohydrates (as is), compared with a voluntary selection of a diet with a protein-fat-carbohydrate energy balance of 52:36:12 for cats ${ }^{(108)}$ and of 30:63:7 for dogs ${ }^{(109)}$. A test diet with a carbohydrate content at $25 \%$ ME resulted in a lower peak and postprandial glucose concentration compared with diets with a carbohydrate content at 45 and $55 \% \mathrm{ME}$, although all measured glucose levels were within normal reference ranges ${ }^{(110)}$ Whether dogs and cats have the capacity to protect against increased blood glucose levels when fed commercial diets compared with their natural diet remains to be determined. It was recently demonstrated that the proportion of dry food intake may not be a risk factor for the development of type 2 diabetes mellitus in cats ${ }^{(111)}$; however, the study did not take into account the composition of the food or specific absorption of dietary AGE. Whether increased AGE exposure contributes to the pathogenesis of the aforementioned diseases in $\operatorname{dogs}(17,87-91)$ and possibly cats warrants further study. Given the key role of the kidney in the elimination and detoxification of AGE, cats and dogs with conditions such as chronic kidney disease 
will probably have an impaired capacity to eliminate AGE, which causes a build-up of AGE, formation of new AGE in the body and contributes to the pathogenesis of various health conditions. Whether or not dietary AGE intake also plays a pivotal role in the development of diabetes mellitus in dogs and cats, as suggested by Vlassara \& Striker ${ }^{(75)}$ in humans, is unknown, as is the potential of AGE restriction as a cost-effective strategy in the prevention and treatment of diabetes mellitus in dogs and cats.

\section{Early Maillard reaction products in ingredients and during processing of pet foods}

The amount of early (and advanced) MRP in pet foods may originate from three sources: first, the pet food ingredients may already contain early MRP due to processing; second, the processing conditions applied to produce the actual pet food; and third, lysine may react during coating and storage of the pet food.

\section{Early Maillard reaction products in pet food ingredients}

Most pet food manufacturers use co-products from other industries that may have been processed to varying degrees as primary ingredients in pet foods ${ }^{(12)}$. Proteins in pet foods originate from both animal and vegetable ingredients ${ }^{(112)}$. Animal protein sources in pet food include meat and bone meals of poultry, beef, pig, lamb and/or fish and other animal co-products, many of which are manufactured by a rendering-process ${ }^{(113)}$. Rendering separates fat, removes water and eradicates bacteria at temperatures as high as $130^{\circ} \mathrm{C}$ for several hours. These high temperatures and the duration of processing can influence protein quality. Using a chicken growth assay, total lysine availability in raw animal meals ranged from 86.9 to $107 \cdot 7 \%$ whereas in the rendered animal meals lysine availability ranged from $70 \cdot 1$ to $99 \cdot 9 \%{ }^{(114)}$. Differences between total and reactive lysine content in several ingredients of animal origin, mostly rendered meat meals, range from $1.0 \%$ to up to $36.0 \%$ (Table 1 ). The difference between total and reactive lysine content in fish meals is, on average, less $(4.0 \%)$ compared with meat and bone meal (16.0\%), poultry meal $(17 \cdot 0 \%)$ and meat meal (20.0\%), although variation is also high within these ingredients of animal origin.

Proteins of vegetable origin in pet foods originate from cereal grains and soyabean meal. These proteins are often considered to be of lower nutritional quality compared with animal proteins, because of a lower content of some essential amino acids and the presence of antinutritional factors ${ }^{(115)}$. In particular, cereal proteins are relatively low in lysine (Table 1 ). The difference between total and reactive lysine content in several ingredients of vegetable origin ranges from 0 to $44.0 \%$ (Table 1 ). The difference between total and reactive lysine content in peas and soyabean meal is, on average, less (0 and $6.0 \%$, respectively) compared with wheat (15.0\%), barley $(15 \cdot 0 \%)$, maize $(27 \cdot 0 \%)$ and rice $(17 \cdot 0 \%)$. In cereals, differences between total and reactive lysine content are higher compared with non-cereal ingredients of vegetable origin, with an average difference of $17 \cdot 0 v .7 \cdot 0 \%$, respectively. Vegetable ingredients are often dried and ground before being included in the pet food recipe. Both drying and grinding involve heat during the process.

The data in Table 1 indicate that part of the lysine in animal and vegetable protein sources has already gone through the early Maillard reaction before inclusion in pet food recipes. Given the use of meat meals as main protein sources in pet foods, it would, therefore, be of interest to evaluate where and how early MRP are formed in these ingredients, which may ultimately contribute to the reduction of the difference between total and reactive lysine content in pet foods.

\section{Effect of processing of pet foods}

Pet foods are produced utilising various process technologies. Dry pet foods are the most popular form of dog and cat food ${ }^{(1)}$ and most often produced by extrusion cooking. Next to extrusion cooking, dry foods can also be manufactured by pelleting the ingredient mixture. Moist foods are manufactured using heat sterilisation using retorting processing. Every processing technology has its own characteristic process conditions, thereby having a greater or lesser impact on the rate and extent of the Maillard reaction. The effect of processing on the Maillard reaction is expressed in terms of a change in total and reactive lysine content. As the Maillard reaction can decrease total lysine content due to its conversion into advanced MRP, the calculated difference between total and reactive lysine content can give an underestimation of the effect of processing on the Maillard reaction. In addition, small changes in total and reactive lysine contents should be interpreted with care, as the CV in amino acid analysis can be as high as 3\% for total lysine ${ }^{(116)}$. For reactive lysine, extra steps in the analysis can cause a higher CV compared with total lysine.

Extrusion. Extrusion cooking is a high-temperature, short-time treatment to improve the digestibility of raw ingredients and allows expansion, dehydration and shaping of the kibbles. The extruder consists of a feeder, preconditioner, extruder barrel, die and a knife assembly ${ }^{(117)}$. The feeder controls the feed rate or throughput of the raw ingredients into the preconditioner. The main function of the preconditioner is to mix the ingredients with water and steam and to pre-cook the ingredients. The extruder barrel is a fixed metal barrel that contains one or two screws to transport the (pre-cooked) ingredient mix from the inlet zone to the die. The temperature inside the barrel is increased, resulting in cooking of the mix. Pet foods are generally extruded using temperatures between 80 and $200^{\circ} \mathrm{C}$ for 10 to $270 \mathrm{~s}$, with moisture levels of 10 to $25 \%{ }^{(118)}$. 
At the end of the extruder barrel, a die is installed that restricts the product flow, causing increased pressure and shear. Moisture evaporates rapidly when the extrudate exits the die and encounters ambient pressure and temperature, which causes expansion and creates the characteristic texture of dry extruded pet food ${ }^{(117)}$ In addition, the die and a knife assembly behind the die are responsible for the shape of the product. The kibbles are then dried to reduce the moisture content to less than 6-9\%. Dryers usually consist of a heating zone, where the

Table 1. Total and reactive lysine contents of common pet food ingredients ${ }^{\star}$

\begin{tabular}{|c|c|c|c|c|c|c|c|}
\hline \multirow[b]{2}{*}{ Ingredient } & \multicolumn{2}{|c|}{ Lysine ( $\mathrm{g} / \mathrm{kg}$ as is) } & \multirow[b]{2}{*}{ Method } & \multirow[b]{2}{*}{$\mathrm{RL} / \mathrm{TL}$} & \multirow[b]{2}{*}{$\mathrm{CP}(\mathrm{g} / \mathrm{kg})$} & \multirow[b]{2}{*}{ DM (g/kg) } & \multirow[b]{2}{*}{ Reference } \\
\hline & Total† & Reactiveł & & & & & \\
\hline \multicolumn{8}{|l|}{ Animal origin } \\
\hline \multirow{5}{*}{ Fish meal } & $46 \cdot 9$ & $46 \cdot 5$ & FDNB & 0.99 & $625 \S$ & $912 \S$ & Hurrell et al. ${ }^{(39)}$ \\
\hline & $51 \cdot 0$ & $45 \cdot 9$ & FDNB & 0.90 & 649 & 867 & Batterham et al. ${ }^{(140)}$ \\
\hline & $51 \cdot 7$ & $51 \cdot 0$ & OMIU & 0.99 & 703 & 917 & $\operatorname{Tran}^{(123)}$ \\
\hline & $47 \cdot 0$ & 45.9 & OMIU & 0.98 & $625 \S$ & 925 & van der Poel \& Bikker $\|$ \\
\hline & $51 \cdot 1$ & $46 \cdot 9$ & OMIU & 0.92 & 635 & 983 & Morel et al. ${ }^{(141)}$ \\
\hline \multirow{8}{*}{ Meat and bone meal } & 24.8 & $23 \cdot 7$ & FDNB & 0.96 & $509 \S$ & $940 \S$ & Hurrell et al. ${ }^{(39)}$ \\
\hline & 24.0 & $18 \cdot 7$ & FDNB & 0.78 & 494 & 967 & Batterham et al. ${ }^{(142)}$ \\
\hline & $37 \cdot 0$ & $32 \cdot 6$ & FDNB & 0.88 & 513 & 952 & \\
\hline & 34.0 & $29 \cdot 6$ & FDNB & 0.87 & 430 & 926 & \\
\hline & $22 \cdot 0$ & $18 \cdot 7$ & FDNB & 0.85 & 431 & 928 & \\
\hline & 28.0 & $22 \cdot 1$ & FDNB & 0.79 & 527 & 935 & Batterham et al. ${ }^{(140)}$ \\
\hline & 36.5 & 34.6 & OMIU & 0.95 & $509 \S$ & $940 \S$ & Rutherfurd et al. ${ }^{(41)}$ \\
\hline & $27 \cdot 4$ & 17.4 & OMIU & 0.64 & 491 & 932 & Morel et al. ${ }^{(141)}$ \\
\hline \multirow[t]{4}{*}{ Meat meal } & $27 \cdot 0$ & $21 \cdot 3$ & FDNB & 0.79 & 547 & 946 & Batterham et al. ${ }^{(142)}$ \\
\hline & $26 \cdot 0$ & $21 \cdot 8$ & FDNB & 0.84 & 507 & 936 & \\
\hline & $29 \cdot 0$ & $22 \cdot 3$ & FDNB & 0.77 & 559 & 946 & \\
\hline & $32 \cdot 0$ & $26 \cdot 2$ & FDNB & 0.82 & 532 & 945 & \\
\hline Chicken meat & 11.8 & $9 \cdot 1$ & OMIU & 0.78 & 213 & 442 & $\operatorname{Tran}^{(123)}$ \\
\hline Poultry meal & 35.4 & $29 \cdot 3$ & OMIU & 0.83 & 652 & 960 & \\
\hline \multirow[t]{2}{*}{ Blood meal } & $89 \cdot 1$ & 88.0 & OMIU & 0.99 & 9279 & 9379 & Rutherfurd et al. ${ }^{(41)}$ \\
\hline & $85 \cdot 2$ & 61.5 & OMIU & 0.72 & 920 & 914 & Morel et al. ${ }^{(141)}$ \\
\hline \multicolumn{8}{|l|}{ Vegetable origin } \\
\hline \multirow[t]{4}{*}{ Wheat } & $3 \cdot 1$ & 2.4 & OMIU & 0.78 & 94 & 871 & $\operatorname{Tran}^{(123)}$ \\
\hline & 3.5 & $3 \cdot 1$ & OMIU & 0.89 & $137 \S$ & $897 \S$ & Rutherfurd et al. ${ }^{(41)}$ \\
\hline & $3 \cdot 1$ & $2 \cdot 8$ & OMIU & 0.90 & $137 \S$ & 873 & van der Poel \& Bikker $\|$ \\
\hline & 3.4 & $2 \cdot 9$ & OMIU & 0.85 & 120 & 867 & Morel et al. ${ }^{(141)}$ \\
\hline \multirow[t]{4}{*}{ Barley } & 5.9 & $5 \cdot 4$ & FDNB & 0.92 & $123 \S$ & $902 \S$ & Hurrell et al. ${ }^{(39)}$ \\
\hline & 3.7 & $3 \cdot 1$ & OMIU & 0.84 & 110 & 883 & $\operatorname{Tran}^{(123)}$ \\
\hline & $3 \cdot 6$ & $3 \cdot 1$ & OMIU & 0.86 & $123 \S$ & 875 & van der Poel \& Bikker\| \\
\hline & 4.6 & 3.6 & OMIU & 0.78 & 97 & 877 & Morel et al. ${ }^{(141)}$ \\
\hline \multirow[t]{3}{*}{ Maize } & $2 \cdot 4$ & 1.8 & OMIU & 0.75 & 81 & 876 & $\operatorname{Tran}^{(123)}$ \\
\hline & 2.5 & $2 \cdot 2$ & OMIU & 0.88 & $84 \S$ & 869 & van der Poel \& Bikker $\|$ \\
\hline & $2 \cdot 7$ & 1.5 & OMIU & 0.56 & 83 & 876 & Morel et al. ${ }^{(141)}$ \\
\hline Maize gluten & 8.2 & 8.3 & FDNB & 1.01 & $563 \S$ & $865 \S$ & Hurrell et al. ${ }^{(39)}$ \\
\hline Rice & 3.0 & 2.5 & OMIU & 0.83 & 80 & 870 & $\operatorname{Tran}^{(123)}$ \\
\hline \multirow[t]{2}{*}{ Soyabean (full fat) } & $22 \cdot 4$ & 22.5 & OMIU & 1.00 & $381 \S$ & 907 & van der Poel \& Bikker\| \\
\hline & $24 \cdot 3$ & $22 \cdot 1$ & OMIU & 0.91 & 421 & 968 & Morel et al. ${ }^{(141)}$ \\
\hline \multirow[t]{6}{*}{ Soyabean meal } & 30.9 & $30 \cdot 8$ & FDNB & 1.00 & $515 \S$ & $928 \S$ & Hendriks et al. \\
\hline & $33 \cdot 2$ & $31 \cdot 1$ & FDNB & 0.94 & $515 \S$ & $928 \S$ & Hurrell et al. ${ }^{(39)}$ \\
\hline & $30 \cdot 0$ & $23 \cdot 1$ & FDNB & 0.77 & 475 & 890 & Batterham et al. ${ }^{(140)}$ \\
\hline & $32 \cdot 3$ & $32 \cdot 3$ & OMIU & 1.00 & $515 \S$ & $928 \S$ & Rutherfurd et al. ${ }^{(41)}$ \\
\hline & $29 \cdot 3$ & $29 \cdot 1$ & OMIU & 0.99 & $515 \S$ & 886 & van der Poel \& Bikker\| \\
\hline & $31 \cdot 0$ & $29 \cdot 0$ & OMIU & 0.94 & 416 & 885 & Morel et al. \\
\hline \multirow[t]{4}{*}{ Pea } & $15 \cdot 1$ & $14 \cdot 7$ & FDNB & 0.97 & 2119 & 8679 & Hendriks et al. ${ }^{(30)}$ \\
\hline & $14 \cdot 8$ & $15 \cdot 4$ & OMIU & 1.04 & 2119 & 868 & van der Poel \& Bikker\| \\
\hline & 14.9 & 14.9 & FDNB & 1.00 & 210 & 914 & Van Barneveld \& Batterham ${ }^{(143)}$ \\
\hline & 17.5 & $13 \cdot 8$ & OMIU & 0.79 & 192 & 875 & Morel et al. ${ }^{(141)}$ \\
\hline Pea flour & $15 \cdot 3$ & 14.5 & FDNB & 0.95 & 2119 & 8679 & Hurrell et al. ${ }^{(39)}$ \\
\hline DDGS (wheat) & $7 \cdot 0$ & 5.5 & OMIU & 0.79 & $268 \S$ & 912 & van der Poel \& Bikker\| \\
\hline & 6.4 & $5 \cdot 1$ & FDNB & 0.79 & 335 & 928 & Cozannet et al. ${ }^{(144)}$ \\
\hline
\end{tabular}

$\mathrm{RL}$, reactive lysine; TL, total lysine; $\mathrm{CP}$, crude protein; FDNB, fluorodinitrobenzene; OMIU, O-methylisourea; DDGS, distillers dried grains with solubles.

${ }^{*}$ Pet food ingredients used in dog and cat foods according to the National Research Council ${ }^{(16)}$.

†Total lysine was determined by conventional amino acid analysis.

¥Reactive lysine was determined according to the given method.

$\S$ Missing values for DM and CP were completed with the help of data from the National Research Council ${ }^{(16)}$. Values were necessary to calculate results in $\mathrm{g} / \mathrm{kg}$ from the original publications.

$\|$ AFB van der Poel and $P$ Bikker, unpublished results.

I Missing values for DM and CP were completed with the help of data from the CVB ${ }^{(145)}$ 
Table 2. Overview of extrusion parameters in relation to total and reactive lysine content of several foods and ingredients

\begin{tabular}{|c|c|c|c|c|c|c|c|}
\hline \multirow[b]{2}{*}{ Food/ingredient } & & \multicolumn{2}{|c|}{ Lysine ( $\mathrm{g} / \mathrm{kg}$ as is) } & \multirow[b]{2}{*}{$\mathrm{RL} / \mathrm{TL}$} & \multirow[b]{2}{*}{ Method } & \multirow[b]{2}{*}{ Additional settings } & \multirow[b]{2}{*}{ Reference } \\
\hline & & Total $^{*}$ & Reactive $†$ & & & & \\
\hline \multicolumn{8}{|l|}{ Temperature $\left({ }^{\circ} \mathrm{C}\right)$} \\
\hline \multirow[t]{4}{*}{ Dog food } & UP & $8 \cdot 3$ & 5.9 & 0.71 & \multirow[t]{4}{*}{ OMIU } & \multirow{4}{*}{$\begin{array}{l}\text { Co-rotating twin screw extruder; } \\
\text { length:diameter ratio } 25 ; \text { screw } \\
\text { speed } 200 \mathrm{rpm} \text {; feed rate } 14.1 \mathrm{~kg} / \mathrm{h} \text {; } \\
\text { two die orifices } 0.8 \mathrm{~cm}\end{array}$} & \multirow[t]{4}{*}{ Lankhorst et al. ${ }^{(127)}$} \\
\hline & 110 & 8.4 & $7 \cdot 1$ & 0.85 & & & \\
\hline & 130 & 8.5 & 8.5 & 1.01 & & & \\
\hline & 150 & $8 \cdot 1$ & $8 \cdot 0$ & 0.98 & & & \\
\hline \multirow[t]{2}{*}{ Dog food } & UP & 9.9 & $7 \cdot 4$ & 0.75 & \multirow[t]{2}{*}{ OMIU } & \multirow{2}{*}{$\begin{array}{l}\text { Co-rotating twin screw extruder; } \\
\text { length:diameter ratio } 25 \text {; screw } \\
\text { speed } 150 \mathrm{rpm} \text {; two die orifice } \\
\text { diameters } 0.8 \mathrm{~cm} \text {; moisture } 300 \mathrm{~g} / \mathrm{kg}\end{array}$} & $\operatorname{Tran}^{(123)}$ \\
\hline & 120 & $8 \cdot 7$ & $6 \cdot 5$ & 0.75 & & & \\
\hline Fish meal & UP & $56 \cdot 3$ & $55 \cdot 6$ & 0.99 & & & \\
\hline & 120 & $56 \cdot 8$ & $52 \cdot 1$ & 0.92 & & & \\
\hline Poultry meal & UP & $36 \cdot 9$ & $30 \cdot 6$ & 0.83 & & & \\
\hline & 120 & $35 \cdot 8$ & 31.9 & 0.89 & & & \\
\hline Chicken meat & UP & $26 \cdot 6$ & $20 \cdot 7$ & 0.78 & & & \\
\hline & 120 & $21 \cdot 6$ & $17 \cdot 0$ & 0.77 & & & \\
\hline Barley & UP & $4 \cdot 2$ & 3.5 & 0.83 & & & \\
\hline & 120 & 4.4 & 2.5 & 0.57 & & & \\
\hline Wheat & UP & $3 \cdot 6$ & $2 \cdot 8$ & 0.78 & & & \\
\hline & 120 & 3.5 & $2 \cdot 7$ & 0.77 & & & \\
\hline Dehulled rice & UP & 3.5 & 2.9 & 0.83 & & & \\
\hline & 120 & $3 \cdot 2$ & 3.5 & 1.09 & & & \\
\hline Maize & UP & $2 \cdot 8$ & $2 \cdot 1$ & 0.75 & & & \\
\hline & 120 & $2 \cdot 9$ & $2 \cdot 3$ & 0.79 & & & \\
\hline Soyabean meal & UP & $30 \cdot 9$ & $30 \cdot 8$ & 1.00 & FDNB & Experimental single screw extruder; & Hendriks et al..$^{(30)}$ \\
\hline & 90 & $31 \cdot 0$ & $29 \cdot 8$ & 0.96 & & die orifice $0.8 \mathrm{~cm}$; screw speed $80 \mathrm{rpm}$ & \\
\hline & 115 & $31 \cdot 7$ & $29 \cdot 8$ & 0.94 & & feed rate $200 \mathrm{~g} / \mathrm{min}$ & \\
\hline & 140 & $30 \cdot 0$ & $27 \cdot 3$ & 0.91 & & & \\
\hline Pea & UP & $15 \cdot 1$ & $14 \cdot 7$ & 0.97 & FDNB & Experimental twin screw extruder; & \\
\hline & 105 & $15 \cdot 1$ & $14 \cdot 7$ & 0.97 & & die surface $1.245 \mathrm{~cm}^{2} ;$ screw & \\
\hline & 125 & $15 \cdot 4$ & $14 \cdot 6$ & 0.95 & & speed $48 \mathrm{rpm}$; feed rate $500 \mathrm{~g} / \mathrm{min}$ & \\
\hline & 140 & $15 \cdot 0$ & $13 \cdot 2$ & 0.88 & & & \\
\hline Rice flour variety 1 & UP & $2 \cdot 6$ & - & - & - & Twin screw extruder; die orifice $0.4 \mathrm{~cm}$; & Eggum et al. ${ }^{(124)}$ \\
\hline & 120 & $2 \cdot 7$ & - & - & & barrel length $46 \mathrm{~cm}$; barrel diameter & \\
\hline & 135 & $2 \cdot 7$ & - & - & & $3.77 \mathrm{~cm}$; screw diameter $3.74 \mathrm{~cm}$ & \\
\hline & 150 & $2 \cdot 4$ & - & - & & $\begin{array}{l}\text { moisture content } 15 \% \text {; screw } \\
\text { speed } 140 \text { rom: barrel pressure } 45 \text { bars }\end{array}$ & \\
\hline Rice flour variety 2 & UP & $3 \cdot 2$ & - & - & & & \\
\hline & 120 & $3 \cdot 0$ & - & - & & & \\
\hline & 135 & $2 \cdot 7$ & - & - & & & \\
\hline & 150 & $2 \cdot 9$ & - & - & & & \\
\hline Glutinous rice-based & UP & - & $8 \cdot 2$ & - & OMIU & Co-rotating twin screw extruder; & Chaiyakul et al. ${ }^{(125)}$ \\
\hline snack protein $20 \%$ & 150 & - & $8 \cdot 3$ & - & & screw length $70 \mathrm{~cm}$; feed rate $12 \mathrm{~kg} / \mathrm{h}$; & \\
\hline & 180 & - & $7 \cdot 6$ & - & & die orifice $0.3 \mathrm{~cm}$; screw speed $400 \mathrm{rpm}$ & \\
\hline Glutinous rice-based & UP & - & $12 \cdot 0$ & - & & & \\
\hline snack protein $30 \%$ & 150 & - & $10 \cdot 9$ & - & & & \\
\hline & 180 & - & $10 \cdot 0$ & - & & & \\
\hline Cowpea & UP & - & $\downarrow \ddagger$ & - & FDNB & Pilot plant extruder; die orifice $0.635 \mathrm{~cm}$; & Pham \& Delrosario ${ }^{(126}$ \\
\hline & 93 & - & & - & & barrel length $115 \mathrm{~cm}$; internal & \\
\hline & 112 & - & & - & & diameter $5.715 \mathrm{~cm}$; compression type screw & \\
\hline & 132 & - & & - & & & \\
\hline Mung bean & UP & - & $\downarrow$ & - & & & \\
\hline & 93 & - & & - & & & \\
\hline & 112 & - & & - & & & \\
\hline & 132 & - & & - & & & \\
\hline Moisture content (\%) & & & & & & & \\
\hline Dog food & 20 & $8 \cdot 2$ & $8 \cdot 0$ & 0.97 & OMIU & Co-rotating twin screw extruder; throughput & Lankhorst et al. $^{(127)}$ \\
\hline & 30 & $8 \cdot 4$ & $7 \cdot 7$ & 0.92 & & $\begin{array}{l}14.1 \mathrm{~kg} / \mathrm{h} \text {; die diameter } 8 \mathrm{~mm} \text {; } \\
\text { temperature } 110^{\circ} \mathrm{C}\end{array}$ & \\
\hline Glutinous rice-based & 20 & - & $7 \cdot 7$ & - & OMIU & Co-rotating twin screw extruder; & Chaiyakul et al. ${ }^{(125)}$ \\
\hline snack protein $20 \%$ & 25 & - & $8 \cdot 0$ & - & & screw length $70 \mathrm{~cm}$; feed rate $12 \mathrm{~kg} / \mathrm{h}$; & \\
\hline & 30 & - & $7 \cdot 8$ & - & & die orifice $0.3 \mathrm{~cm}$; screw speed $400 \mathrm{rpm}$ & \\
\hline Glutinous rice-based & 20 & - & $9 \cdot 8$ & - & & & \\
\hline snack protein $30 \%$ & 25 & - & $10 \cdot 3$ & - & & & \\
\hline & 30 & - & $11 \cdot 1$ & - & & & \\
\hline
\end{tabular}


Table 2. Continued

\begin{tabular}{|c|c|c|c|c|c|c|c|}
\hline \multirow[b]{2}{*}{ Food/ingredient } & & \multicolumn{2}{|c|}{ Lysine ( $\mathrm{g} / \mathrm{kg}$ as is) } & \multirow[b]{2}{*}{$\mathrm{RL} / \mathrm{TL}$} & \multirow[b]{2}{*}{ Method } & \multirow[b]{2}{*}{ Additional settings } & \multirow[b]{2}{*}{ Reference } \\
\hline & & Total $^{*}$ & Reactive & & & & \\
\hline \multirow[t]{4}{*}{ Soyabean meal } & 25 & $32 \cdot 3$ & $30 \cdot 3$ & 0.94 & \multirow[t]{6}{*}{ FDNB } & \multirow{5}{*}{$\begin{array}{l}\text { Experimental single screw extruder; } \\
\text { die orifice } 0.8 \mathrm{~cm} \text {; screw speed } 80 \mathrm{rpm} \text {; } \\
\text { feed rate } 200 \mathrm{~g} / \mathrm{min}\end{array}$} & \multirow[t]{6}{*}{ Hendriks et al. ${ }^{(30)}$} \\
\hline & 27 & $30 \cdot 3$ & 28.9 & 0.95 & & & \\
\hline & 30 & 30.7 & 28.6 & 0.93 & & & \\
\hline & 40 & $30 \cdot 5$ & $28 \cdot 0$ & 0.92 & & & \\
\hline \multirow[t]{2}{*}{ Pea } & 15 & $16 \cdot 1$ & $14 \cdot 2$ & 0.88 & & & \\
\hline & 30 & $16 \cdot 3$ & $15 \cdot 6$ & 0.96 & & $\begin{array}{l}\text { Experimental twin screw extruder; } \\
\text { die surface } 1.245 \mathrm{~cm}^{2} ; \text { screw } \\
\text { speed } 48 \mathrm{rpm} \text {; feed rate } 500 \mathrm{~g} / \mathrm{min}\end{array}$ & \\
\hline \multirow[t]{3}{*}{ Cowpea } & 30 & - & $\downarrow$ & - & \multirow[t]{6}{*}{ FDNB } & \multirow{6}{*}{$\begin{array}{l}\text { Pilot plant extruder; die orifice } 0.635 \mathrm{~cm} \text {; } \\
\text { barrel length } 115 \mathrm{~cm} \text {; internal } \\
\text { diameter } 5.715 \mathrm{~cm} \text {; compression } \\
\text { type screw; measured at a } \\
\text { given temperature }\end{array}$} & \multirow[t]{6}{*}{ Pham \& Delrosario ${ }^{(126)}$} \\
\hline & 37.5 & - & & - & & & \\
\hline & 45 & - & & - & & & \\
\hline \multirow[t]{3}{*}{ Mung bean } & 30 & - & \multirow[t]{3}{*}{$\downarrow$} & - & & & \\
\hline & 37.5 & - & & - & & & \\
\hline & 45 & - & & - & & & \\
\hline \multicolumn{8}{|l|}{ Screw speed (rpm) } \\
\hline \multirow[t]{3}{*}{ Cowpea } & 100 & - & $\uparrow$ & - & \multirow[t]{6}{*}{ FDNB } & \multirow{6}{*}{$\begin{array}{l}\text { Pilot plant extruder; die orifice } 0.635 \mathrm{~cm} \text {; } \\
\text { barrel length } 115 \mathrm{~cm} \text {; internal } \\
\text { diameter } 5.715 \mathrm{~cm} \text {; compression type screw }\end{array}$} & \multirow[t]{6}{*}{ Pham \& Delrosario ${ }^{(126)}$} \\
\hline & 140 & - & & - & & & \\
\hline & 200 & - & & - & & & \\
\hline \multirow[t]{3}{*}{ Mung bean } & 100 & - & $\uparrow$ & - & & & \\
\hline & 140 & - & & - & & & \\
\hline & 200 & - & & - & & & \\
\hline \multirow{5}{*}{$\begin{array}{l}\text { Soya-sweet } \\
\text { potato mixture }\end{array}$} & 80 & - & $\uparrow$ & - & \multirow[t]{5}{*}{ OPA } & \multirow{6}{*}{$\begin{array}{l}\text { Experimental single screw extruder; } \\
\text { length:diameter ratio } 16: 1 \text {; compression } \\
\text { ratio } 1: 1 \cdot 15 ; \text { moisture } 18 \% \text {; } \\
\text { temperature } 100^{\circ} \mathrm{C}\end{array}$} & \multirow[t]{5}{*}{ Iwe et al. ${ }^{(129)}$} \\
\hline & 92 & - & & - & & & \\
\hline & 110 & - & & - & & & \\
\hline & 127 & - & & - & & & \\
\hline & 140 & - & & - & & & \\
\hline Die size $(\mathrm{mm})$ & & & & & & & \\
\hline Dog food & 4 & $7 \cdot 9$ & $7 \cdot 2$ & 0.90 & OMIU & Single screw extruder; length:diameter & Tran et al. ${ }^{(131)}$ \\
\hline & 8 & $8 \cdot 3$ & $7 \cdot 2$ & 0.86 & & $\begin{array}{l}\text { ratio } 8 ; \text { temperature } 130^{\circ} \mathrm{C} \text {; } \\
\text { moisture } 300 \mathrm{~g} / \mathrm{kg}\end{array}$ & \\
\hline Soya-sweet & 6 & - & $\downarrow$ & & OPA & Experimental single screw extruder; & Iwe et al. ${ }^{(129)}$ \\
\hline potato mixture & 7 & - & & & & length:diameter ratio 16:1; compression & \\
\hline & 8 & - & & & & ratio $1: 1 \cdot 15 ;$ moisture $18 \%$ & \\
\hline & 9 & - & & & & temperature $100^{\circ} \mathrm{C}$ & \\
\hline & 10 & - & & & & & \\
\hline
\end{tabular}

RL, reactive lysine; TL, total lysine; UP, unprocessed; OMIU, O-methylisourea; FDNB, fluorodinitrobenzene; OPA, ortho-phthaldialdehyde.

* Total lysine is determined with conventional amino acid analysis.

† Reactive lysine is determined according to the given method.

‡Data of reactive lysine content were not presented by authors. Arrows indicate a decrease $(\downarrow)$ and an increase $(\uparrow)$ in reactive lysine content with increasing parameter.

kibbles are heated to about $80-100^{\circ} \mathrm{C}$. The product is then moved into the drying zone with temperatures of about $120-150^{\circ} \mathrm{C}$. Finally, the product is cooled to $80-100^{\circ} \mathrm{C}$. This type of drying takes about $15 \mathrm{~min}$ for drying and $7 \mathrm{~min}$ for cooling ${ }^{(118)}$. Finally the pet food is coated with fat and/or a palatability enhancer and subsequently packaged. The extrusion process is controlled by several process parameters. Raw materials and screw configuration as well as die size are set before extrusion. Process parameters such as moisture content, screw speed and barrel temperature can be adjusted and continuously monitored during extrusion. Variables such as retention time, product temperature, pressure and mechanical energy change as a result of changing one or more of the process parameters ${ }^{(119)}$.

The effects of the process parameters, i.e. temperature, moisture and mechanical shear, on pet foods and pet food ingredients in relation to total and reactive lysine content are summarised in Table 2 . It is commonly accepted that temperature is the most important process parameter for the Maillard reaction during extrusion ${ }^{(4,120-122)}$. In general, the rate of Maillard reaction increases with temperature and time, resulting in a decrease in reactive lysine content and an increase in the formation of MRP as indicated in model systems ${ }^{(50)}$. Several studies have examined the effect of extrusion temperatures on total and reactive lysine content in food recipes and in various single ingredients. $\operatorname{Tran}^{(123)}$ reported that extrusion at $120^{\circ} \mathrm{C}$ of an experimental dog food did not affect the difference between total and OMIU-reactive lysine content, which remained at $25 \cdot 0 \%$, but resulted in a $12 \cdot 1$ and $12 \cdot 2 \%$ reduction, respectively, of total and OMIU-reactive lysine content compared with the unextruded food mixture. Furthermore, this study reported that extrusion can have contradictory effects on total and OMIU-reactive lysine between ingredients used in this food mixture. Extrusion at $120^{\circ} \mathrm{C}$ of chicken meat 
and fish meal resulted in an OMIU-reactive lysine loss of 17.9 and $6.3 \%$ whereas extrusion had little effect on OMIUreactive lysine content of poultry meal. Furthermore, total lysine contents in chicken meat decreased by $18.8 \%$ after extrusion, $3.0 \%$ for poultry meal and slightly increased for fish meal (0.9\%). For ingredients of vegetable origin, total lysine contents were low overall and decreased after extrusion for wheat $(2.8 \%)$ and dehulled rice $(8.6 \%)$, whereas total lysine content increased for barley (4.8\%) and maize (9.5\%). OMIU-reactive lysine contents were decreased after extrusion for barley (28.6\%) and wheat (3.6\%), whereas increased contents were reported for dehulled rice $(20.7 \%)$ and maize $(9.5 \%)$. As the vegetable ingredients studied were low in lysine content, the contribution of a possible error of the assay to a relative change in lysine content would have been larger than that for the animal-derived ingredients that contained considerably more lysine. The data of Tran ${ }^{(123)}$, however, do not show the effect of lower or higher extrusion temperature on total and reactive lysine content in foods or its ingredients. Extrusion of soyabean meal or peas had no effect on total lysine content and little effect on FDNB-reactive lysine content when extruded at 90 or $115^{\circ} \mathrm{C}$ and 105 or $125^{\circ} \mathrm{C}$, respectively ${ }^{(30)}$. Extrusion at $140^{\circ} \mathrm{C}$, however, decreased FDNB-reactive lysine content by $11 \cdot 4 \%$ for soyabean meal and $10 \cdot 2 \%$ for peas. Extrusion of two rice flour varieties at 120, 130 or $150^{\circ} \mathrm{C}$ had little effect on total lysine contents ${ }^{(124)}$. Extrusion of a glutinous rice-based snack with $20 \%$ protein at $150^{\circ} \mathrm{C}$ had no influence on the OMIU-reactive lysine content; however, it reduced OMIU-reactive lysine content by $9.2 \%$ in a snack with $30 \%$ protein $^{(125)}$. Increasing the extrusion temperature to $180^{\circ} \mathrm{C}$ reduced OMIU-reactive lysine content by $8.4 \%$ for the $20 \%$ protein snack, and by $16.7 \%$ for the $30 \%$ protein snack. Although absolute values were not reported, extrusion of cowpeas and mung beans at temperatures from 93 up to $132^{\circ} \mathrm{C}$ decreased FDNB-reactive lysine content by $25 \cdot 4$ and $21 \cdot 3 \%$, respectively ${ }^{(126)}$. Lankhorst et $a l^{(127)}$ reported that extrusion of an experimental dog food had no effect on total lysine content, but OMIU-reactive lysine content was increased by $20.3 \%$ after extrusion at $110^{\circ} \mathrm{C}$ and $35.6 \%$ after extrusion at $150^{\circ} \mathrm{C}$. At these temperatures, the difference between total and OMIU-reactive lysine content decreased from $29 \cdot 0 \%$ (unprocessed) to $15 \cdot 0$ and $2.0 \%$, respectively. The authors hypothesised that the bound $\varepsilon$-amino group of lysine regained its reactivity as a result of the extrusion process. The underlying mechanism is still unknown; however, based on these data, increasing extrusion temperatures generally reduced reactive lysine contents of single ingredients with little or no effect on total lysine content. The number of studies evaluating the change in total and reactive lysine in pet foods at varying extrusion temperatures is limited, and contradictory effects of temperature on reactive lysine were seen. Additional studies are, therefore, required to assess the importance of extrusion temperature to the formation of MRP in pet foods.
The moisture content of the ingredient or mixture can also be adjusted during extrusion. The moisture content is either the original moisture level of the ingredient or mix itself, or from added water or steam during extrusion. Moisture is necessary for the Maillard reaction to take place $^{(50,128)}$, but moisture also seems to inhibit the browning reaction if present in high concentrations in model systems. Increasing moisture content from 20 to $30 \%$ during extrusion of an experimental dog food only slightly affected total lysine content $(+2 \cdot 4 \%)$ and OMIU-reactive lysine content $(-3.9 \%)^{(127)}$ (Table 2). Moisture content had little effect on OMIU-reactive lysine content for a $20 \%$ protein glutinous rice-based snack but for the $30 \%$ protein snack the OMIU-reactive lysine content was increased by $5 \cdot 1$ and $13.3 \%$ when moisture content was increased from 20 to 25 and $30 \%$, respectively ${ }^{(125)}$. Increasing moisture content from 25 to $40 \%$ during the extrusion of soyabean meal decreased total and FDNB-reactive lysine content by 5.0 and $6.5 \%$, respectively ${ }^{(30)}$. Also for cowpeas and mung beans, FDNB-reactive lysine content has been reported to be decreased with increasing moisture content from 30 to $45 \%$ during extrusion ${ }^{(126)}$. For peas, however, increasing moisture content from 15 to $30 \%$ during extrusion slightly increased total lysine content (1.2\%) and increased FDNB-reactive lysine content by $9.9 \%{ }^{(30)}$. A high moisture content may induce a protective effect by increased or prolonged water evaporation, which keeps product temperature relatively low. In addition, water could reduce friction and, therefore, protects the ingredients from shear during processing.

Mechanical shear force may change during extru$\operatorname{sion}^{(119)}$. The amount of shear force developed during extrusion cooking depends on several process parameters such as screw configuration, compression ratio, screw speed and die size. Literature on the effect of these process parameters in relation to the Maillard reaction is scarce. There are only a few studies that have evaluated the effect of screw speed and die size in relation to reactive lysine content in ingredients or foods, and for most studies no quantitative data are reported (Table 2). There is no information available on the effect of screw speed on total and reactive lysine contents during the extrusion of pet foods. Increasing screw speed during the extrusion of cowpeas and mung beans from 100 to $200 \mathrm{rpm}$ resulted in reduced loss of FDNB-reactive lysine content ${ }^{(126)}$. Similarly, OPA-reactive lysine in a soya-sweet potato mixture resulted in less loss with increasing screw speed from 80 to 140 rpm during extrusion ${ }^{(129)}$. At constant extrusion temperatures, a higher screw speed increases shear but reduces residence time and hence limits the exposure to heat treatment ${ }^{(130)}$. Based on these data, shorter residence time and thus less exposure to heat treatment seem to be more important than the higher shear forces that occur when screw speed is increased. Shear and pressure are also affected by the die at the end of the extruder, which restricts the product flow. Increasing die size from 
4 to $8 \mathrm{~mm}$ in a control sample dried at $40^{\circ} \mathrm{C}$ increased total lysine content in an experimental dog food by $5 \cdot 1 \%$ with no effect on OMIU-reactive lysine ${ }^{(131)}$. Increasing die size from 4 to $9 \mathrm{~mm}$ in the same experimental dog food at four different drying temperatures (80, 120, 160 and $200^{\circ} \mathrm{C}$ ) on average increased OMIU-reactive lysine content with no effect on total lysine. For extrusion of a soyasweet potato mixture, an increase in die size from 6 to $10 \mathrm{~mm}$ at a temperature of $100^{\circ} \mathrm{C}$ reduced OPA-reactive lysine content ${ }^{(129)}$.

Drying and storage. The heat applied during the drying process can also affect the difference between total and reactive lysine. Drying of a dog food at increasing temperatures of $80,120,160$ and $200^{\circ} \mathrm{C}$ to an end moisture content of $6-9 \%$ reduced total lysine content by $15.7 \%$ as well as OMIU-reactive lysine content by $15 \cdot 5 \%{ }^{(131)}$.

Besides drying, addition of palatability enhancers can influence differences between total and reactive lysine in the final product. Flavour and texture are important properties that contribute to the overall palatability of the food, which determines how likely animals are to eat the food. Texture is created during processing; however, dry pet foods often have only moderate inherent flavour ${ }^{(132)}$. Therefore, palatability enhancers are regularly used during the production of dry pet foods. As well as palatability enhancers such as acidified yeast, hydrochloric acid, phosphoric acid, sugars and spices, most dry pet foods are coated with digests ${ }^{(118)}$. Digests are hydrolysed proteins from meats, offals and yeasts, produced using heat and enzymes. The digestion process releases amino acids such as lysine and dipeptides that enhance palatability. However, during this process, the hydrolysed proteins are available to participate in the Maillard reaction. The resulting MRP increase the palatability of the digest ${ }^{(132)}$, but simultaneously result in the formation of early and advanced MRP. The digest is applied as liquid sprayed on the dry food or applied as a powder. It is possible that the production process of digest adds to the differences in total and reactive lysine and to the amount of MRP in dry pet foods.

Little information has been reported on storage conditions and duration in relation to the Maillard reaction in pet foods. Chiang ${ }^{(107)}$ recorded an increase in furosine from $0.91 \mathrm{mg} / \mathrm{g}$ in a control dry dog food to $1.52 \mathrm{mg} / \mathrm{g}$ after storage of 12 weeks at $22 \cdot 2^{\circ} \mathrm{C}$. Storing the same control dry dog food for 12 weeks at $37 \cdot 8^{\circ} \mathrm{C}$ increased furosine levels to $3.19 \mathrm{mg} / \mathrm{g}$. These data are an indication that early Maillard products can be present in pet foods and that additional fructoselysine is generated during storage. No studies have been conducted to determine the stability of reactive lysine in pet foods during varying storage conditions. The data by Chiang ${ }^{(107)}$ indicate that as the furosine concentration increases during storage, the concentration of reactive lysine decreases.

Retorting. Retorting is a processing method in which food contents are sealed in airtight cans, containers, or flexible pouches and are subsequently heat-treated. Process temperatures sterilise the product, resulting in preservation of these high-moisture foods for extended periods of time ${ }^{(118)}$. Moist pet foods contain fresh or frozen meat and other animal tissues, which are ground and homogenised. Additional ingredients such as mash grains or other ground starch sources, vitamin and mineral premixes, and water are added and mixed to create a complete food recipe. The mixture is heated up to $85^{\circ} \mathrm{C}$ to start starch gelatinisation and protein denaturation ${ }^{(118)}$. The hot mixture is transported to machines that fill and seal the packages. A vacuum is created by either the hot product itself, or by injecting steam over the product just before sealing. The steam replaces air in the container, creating under-pressure as the steam condenses during cooling. After sealing, the packages are sterilised in a retort in a continuous or batch system. Retorting is a temperature/ time-dependent process, using an $\mathrm{F}_{0}$-value as a unit to summarise the lethality of the heat employed on the product. The $\mathrm{F}_{0}$-value represents the time equivalent in minutes of a heating process to destroy micro-organisms at the reference temperature of $121 \cdot 1^{\circ} \mathrm{C}^{(133)}$. In general, the process time should be at least $3 \mathrm{~min}$ at $121 \cdot 1^{\circ} \mathrm{C}$ ( $\mathrm{F}_{0}$-value of 3 ) to kill pathogenic bacteria ${ }^{(118)}$. However, higher values $\left(\mathrm{F}_{0}\right.$-value $\left.>10\right)$ are employed in practical pet food production in order to destroy spores ${ }^{(133)}$.

As described above, the difference between total and reactive lysine can be considerable in moist canned foods, with values between 39.0 and $61.8 \%$ (Fig. 5). This indicates that processing conditions applied during retorting of cans favour the Maillard reaction, but effects of processing conditions on total and reactive lysine content have been the subject of only a few experiments. Retorting a standard moist cat food recipe containing a low content of carbohydrates (maximum 6.7\%) at lethality values (F-values) of 5.3, 8.6, 17.2 and 24.3 (temperature set at $121^{\circ} \mathrm{C}$, time periods between 80 to $120 \mathrm{~min}$ ) had no effect on the total or OMIU-reactive lysine content ${ }^{(133)}$. In the unprocessed food, the difference between total and reactive lysine was $12 \cdot 0 \%$. The difference between total and reactive lysine content in the pet food ingredients used in this particular food does not explain the high differences between total and reactive lysine reported in some moist canned foods. True ileal total lysine digestibility as measured using growing rats consistently decreased with increasing F-values from $84.2 \%$ for the untreated food to $77 \cdot 4 \%$ for the food with the highest lethality value $(24.3)^{(133)}$, indicating that part of the lysine was rendered indigestible. However, total as well as OMIU- and FDNB-reactive lysine did not change due to processing. It is therefore unclear whether the Maillard reaction was the cause of the reduced ileal total lysine digestibility. Results of other experiments indicate a decrease in reactive lysine during retorting. Retorting of tuna at $115^{\circ} \mathrm{C}$ for 55 and $90 \mathrm{~min}$ decreased FDNB-reactive lysine contents by 5.0 and $15.7 \%$, respectively ${ }^{(134)}$. Autoclaving a diet used 
for salmonid fish, including fish meal, barley protein concentrate and wheat flour as the main ingredients, at temperatures of $100,110,120$ and $130^{\circ} \mathrm{C}$ reduced total lysine by $5 \cdot 8 \%$ and OMIU-reactive lysine by $18.3 \%{ }^{(135)}$. As FDNB- and OMIU-reactive lysine demonstrate a good correlation $^{(31)}$, results of the effect of retorting on reactive lysine are inconsistent. It is unclear what the contribution is of the ingredient used or the retorting process on the high differences between total and reactive lysine contents reported in moist canned cat foods (Fig. 5). The effects of retorting temperature and its possible interaction with time on total and reactive lysine content have not been studied to date.

Pelleting. Pelleting dry pet foods is a processing technique that is less severe in terms of temperatures applied compared with extrusion $\left(60\right.$ to $90^{\circ} \mathrm{C} \mathrm{v.} 80$ to $\left.200^{\circ} \mathrm{C}\right)$. The pelleting process includes mash conditioning, pelleting and subsequent drying or cooling. For mash conditioning, heat, water and pressure with temperatures between 60 and $90^{\circ} \mathrm{C}^{(136,137)}$ are used to induce a wide range of physical and chemical changes including softening of the food, denaturation of proteins and gelatinisation of $\operatorname{starch}^{(136)}$. After conditioning, the mash is pressed through a die in a pellet mill. The die design is either a ring, which is revolving around fixed rollers, or flat, which is static and horizontal rollers rotate around a vertical axis. The rollers continuously press layers of mash inside the die hole, by which the pellet is built up. The extent of compression is dependent on the height of the layer and the gap distance between the die and the roller. Changing these conditions changes pellet quality. Die holes differ in their length: diameter ratio, influencing the amount of shear that the feed mash receives. After leaving the die, pellets are usually cooled by air flow ${ }^{(136)}$.

Despite the lower processing temperatures, the Maillard reaction occurs during pre-conditioning and/or pelleting, resulting in loss of reactive lysine and formation of MRP. Tran et al. ${ }^{(62)}$ reported a difference of $20.5 \%$ between total and reactive lysine in pelleted commercial dog pellets. There are no reports from experiments in which preconditioning or pelleting conditions were evaluated in terms of influencing total and reactive lysine levels in pelleted pet foods. For pig feed, few studies are available but these only compared unprocessed feed mash with pellets under one fixed pelleting condition. Pelleting pig feed at $80^{\circ} \mathrm{C}$ did not affect total lysine content but slightly increased FDNB-reactive lysine content by up to $1 \cdot 2 \%^{(138)}$. Pelleting a complex nursery pig diet (steamconditioned at $60^{\circ} \mathrm{C}$ for $45 \mathrm{~s}$ through a $5 \times 38 \mathrm{~mm}$ die) had no effect on lysine bioavailability as measured using a standard-curve bioassay with 8 -d-old chicks ${ }^{(137)}$. Pelleting a conventional pre-starter diet for suckling piglets (steamconditioned at $40^{\circ} \mathrm{C}$ for $30 \mathrm{~s}$; pelleted at 60 to $65^{\circ} \mathrm{C}$ through a $1.7 \times 40 \mathrm{~mm}$ die) resulted in a $200 \%$ increase of furosine, a marker for the presence of the Amadori compound of lysine (Fig. 1), from 11.71 to $35 \cdot 18 \mathrm{mg} / \mathrm{kg}^{(139)}$.
Other MRP also increased; HMF increased by $32.6 \%$ from 12.56 to $16.66 \mathrm{mg} / \mathrm{kg}$, and furfural increased from non-detectable to $0.034 \mathrm{mg} / \mathrm{kg}$.

\section{Conclusions}

Data indicate that significant proportions of the lysine in pet foods can be modified and may be unavailable for metabolism by dogs and cats. OMIU-reactive lysine content was below minimal requirement for growing dogs from 4 to 14 weeks in two out of fourteen analysed dry foods. As such, foods for growing dogs require more careful considerations in terms of lysine supply, as the requirement for growing animals is higher than that of adult animals. As batch-to-batch variation is unknown, the results may be different between batches of the same food due to variation in ingredients or processing. More knowledge of the bioavailability of lysine and other amino acids involved in the Maillard reaction in dog and cat foods is required. Advanced MRP have varying biological activities, and in dogs data indicate higher AGE in plasma from dogs suffering from canine diabetes mellitus compared with control animals. In addition, elevated levels of AGE in tissue proteins in dogs were observed for a number of diseases. It is unknown to what extent advanced MRP are present in pet foods. Most of the dietary ingested MRP are rapidly excreted via the kidneys although no data are available for cats and dogs. Whether or not the presence of dietary MRP in pet foods may result in the development of diseases such as diabetes and impaired renal function in pet animals requires further study. In the regulation of the levels of total and reactive lysine and possible advanced MRP in pet foods, control of ingredient processing and choice of ingredients may be a useful strategy as differences between total and reactive lysine are observed in several ingredients commonly used in pet foods. Effects of processing conditions on the difference in total and reactive lysine contents in pet foods are inconsistent and do not always correspond to model systems. Processing temperature is the most important factor followed by moisture level. Moist pet foods appear to have a higher difference between total and reactive lysine content compared with dry foods. Further study into choice of ingredients, extrusion, pelleting and retorting of pet food on the progression of the Maillard reaction is recommended, as are studies on the bioavailability of dietary MRP and their possible relationship with pet health.

\section{Acknowledgements}

The project for which the present review was conducted is jointly financed by the European Union, European Regional Development Fund and The Ministry of Economic Affairs, Agriculture and Innovation, Peaks in the Delta, the Municipality of Groningen, the Province of Groningen, 
MARS Petcare as well as the Dutch Carbohydrate Competence Center (CCC WP 5).

All authors contributed fundamentally to the present paper. C. v. R. contributed to all facets including data collection, calculations and writing the initial manuscript. Other authors contributed to data interpretation and manuscript preparation.

L. A. is an employee of Mars Petcare.

\section{References}

1. Laflamme DP, Abood SK, Fascetti AJ, et al. (2008) Pet feeding practices of dog and cat owners in the United States and Australia. J Am Vet Med Assoc 232, 687-694.

2. Hullar I, Fekete S \& Szocs Z (1998) Effect of extrusion on the quality of soybean-based catfood. J Anim Physiol Anim Nutr 80, 201-206.

3. van der Poel AFB (1990) Effect of processing on antinutritional factors and protein nutritional value of dry beans (Phaseolus vulgaris L.). A review. Anim Feed Sci Technol 29, 179-208.

4. Meade SJ, Reid EA \& Gerrard JA (2005) The impact of processing on the nutritional quality of food proteins. J AOAC Int 88, 904-922.

5. Hodge JE (1953) Dehydrated foods - chemistry of browning reactions in model systems. J Agric Food Chem 1, 928-943.

6. van Boekel M, Fogliano V, Pellegrini N, et al. (2010) A review on the beneficial aspects of food processing. Mol Nutr Food Res 54, 1215-1247.

7. van Boekel MAJS (2006) Formation of flavour compounds in the Maillard reaction. Biotechnol Adv 24, 230-233.

8. Manzocco L, Calligaris S, Mastrocola D, et al. (2000) Review of non-enzymatic browning and antioxidant capacity in processed foods. Trends Food Sci Technol 11, 340-346.

9. Friedman M (1996) Food browning and its prevention: an overview. J Agric Food Chem 44, 631-653.

10. Hurrell RF \& Carpenter KJ (1981) The estimation of available lysine in foodstuffs after Maillard reactions. Prog Food Nutr Sci 5, 159-176.

11. Moughan PJ \& Rutherfurd SM (2008) Available lysine in foods: a brief historical overview. J AOAC Int 91, 901-906.

12. Williams PA, Hodgkinson SM, Rutherfurd SM, et al. (2006) Lysine content in canine diets can be severely heat damaged. J Nutr 136, 1998S-2000S.

13. Rutherfurd SM, Rutherfurd-Markwick KJ \& Moughan PJ (2007) Available (ileal digestible reactive) lysine in selected pet foods. J Agric Food Chem 55, 3517-3522.

14. Moughan PJ (2003) Amino acid availability: aspects of chemical analysis and bioassay methodology. Nutr Res Rev 16, 127-141.

15. Finot PA (2005) The absorption and metabolism of modified amino acids in processed foods. J AOAC Int $\mathbf{8 8}$, 894-903.

16. National Research Council (2006) Nutrient Requirements of Dogs and Cats. Washington, DC: National Academy Press.

17. DeGroot J, Verzijl N, Wenting-van Wijk MJG, et al. (2004) Accumulation of advanced glycation end products as a molecular mechanism for aging as a risk factor in osteoarthritis. Arthritis Rheum 50, 1207-1215.

18. Maillard LC (1912) Action des acides aminés sur les sucres: formation des mélanoidines par voie méthodique (Effect of amino acids on sugars: formation of melanoidins by methodical ways). C R Hebd Sce Acad Sci 154, 66-68.
19. Kwak EJ \& Lim SI (2004) The effect of sugar, amino acid, metal ion, and $\mathrm{NaCl}$ on model Maillard reaction under $\mathrm{pH}$ control. Amino Acids 27, 85-90.

20. Silvan JM, van de Lagemaat J, Olano A, et al. (2006) Analysis and biological properties of amino acid derivates formed by Maillard reaction in foods. J Pharm Biomed Anal 41, 1543-1551.

21. Friedman M (1992) Dietary impact of food-processing. Annu Rev Nutr 12, 119-137.

22. Martins SIFS \& Van Boekel MAJS (2005) A kinetic model for the glucose/glycine Maillard reaction pathways. Food Chem 90, 257-269.

23. Liu SC, Yang DJ, Jin SY, et al. (2008) Kinetics of color development, $\mathrm{pH}$ decreasing, and anti-oxidative activity reduction of Maillard reaction in galactose/glycine model systems. Food Chem 108, 533-541.

24. Nicoli M, Anese M \& Parpinel M (1999) Influence of processing on the antioxidant properties of fruit and vegetables. Trends Food Sci Technol 10, 94-100.

25. Anese M, Manzocco L, Nicoli MC, et al. (1999) Antioxidant properties of tomato juice as affected by heating. J Sci Food Agric 79, 750-754.

26. Anese M, Nicoli MC, Massini R, et al. (1999) Effects of drying processing on the Maillard reaction in pasta. Food Res Int 32, 193-199.

27. Erbersdobler HF \& Somoza V (2007) Forty years of furosine - forty years of using Maillard reaction products as indicators of the nutritional quality of foods. Mol Nutr Food Res 51, 423-430.

28. Wang HY, Qian H \& Yao WR (2011) Melanoidins produced by the Maillard reaction: structure and biological activity. Food Chem 128, 573-584.

29. Mogol BA, Yıldırım A \& Gökmen V (2010) Inhibition of enzymatic browning in actual food systems by the Maillard reaction products. J Sci Food Agric 90, 2556-2562.

30. Hendriks WH, Moughan PJ, Boer H, et al. (1994) Effects of extrusion on the dye-binding, fluorodinitrobenzenereactive and total lysine content of soybean-meal and peas. Anim Feed Sci Technol 48, 99-109.

31. Rutherfurd SM \& Moughan PJ (2007) Development of a novel bioassay for determining the available lysine contents of foods and feedstuffs. Nutr Res Rev 20, 3-16.

32. Moughan PJ (2005) Absorption of chemically unmodified lysine from proteins in foods that have sustained damage during processing or storage. J AOAC Int $\mathbf{8 8}, 949-954$.

33. Carpenter KJ (1960) The estimation of the available lysine in animal-protein foods. Biochem J 77, 604-610.

34. Booth VH (1971) Problems in the determination of FDNB-available lysine. J Sci Food Agric 22, 658-666.

35. Roach AG, Sanderson P \& Williams DR (1967) Comparison of methods for the determination of available lysine value in animal and vegetable protein sources. J Sci Food Agric 18, 274-278.

36. Peterson W \& Warthesen J (1979) Total and available lysine determinations using high-pressure liquid chromatography. J Food Sci 44, 994-997.

37. Kakade ML \& Liener IE (1969) Determination of available lysine in proteins. Anal Biochem 27, 273-280.

38. Couch JR \& Thomas MC (1976) A comparison of chemical methods for the determination of available lysine in various proteins. J Agric Food Chem 24, 943-946.

39. Hurrell RF, Lerman P \& Carpenter KJ (1979) Reactive lysine in foodstuffs as measured by a rapid dye-binding procedure. J Food Sci 44, 1221-1227.

40. Goodno CC, Swaisgood HE \& Catignani GL (1981) A fluorimetric assay for available lysine in proteins. Anal Biochem 115, 203-211. 
41. Rutherfurd SM, Moughan PJ \& van Osch L (1997) Digestible reactive lysine in processed feedstuffs: application of a new bioassay. J Agric Food Chem 45, 1189-1194.

42. Moughan PJ \& Rutherfurd SM (1996) A new method for determining digestible reactive lysine in foods. J Agric Food Chem 44, 2202-2209.

43. Finot P, Bricout J, Viani R, et al. (1968) Identification of a new lysine derivative obtained upon acid hydrolysis of heated milk. Cell Mol Life Sci 24, 1097-1099.

44. Delgado-Andrade C, Rufian-Henares JA \& Morales FJ (2006) Study on fluorescence of Maillard reaction compounds in breakfast cereals. Mol Nutr Food Res 50, 799-804.

45. Assar SH, Moloney C, Lima M, et al. (2009) Determination of $N^{\varepsilon}$-(carboxymethyl)lysine in food systems by ultra performance liquid chromatography-mass spectrometry. Amino Acids 36, 317-326.

46. González-Vega J, Kim B, Htoo J, et al. (2011) Amino acid digestibility in heated soybean meal fed to growing pigs. J Anim Sci 89, 3617-3625.

47. Fontaine J, Zimmer U, Moughan PJ, et al. (2007) Effect of heat damage in an autoclave on the reactive lysine contents of soy products and corn distillers dried grains with solubles. Use of the results to check on lysine damage in common qualities of these ingredients. J Agric Food Chem 55, 10737-10743.

48. Cromwell G, Herkelman K \& Stahly T (1993) Physical, chemical, and nutritional characteristics of distillers dried grains with solubles for chicks and pigs. J Anim Sci 71, 679-686.

49. Van Soest P \& Mason V (1991) The influence of the Maillard reaction upon the nutritive value of fibrous feeds. Anim Feed Sci Technol 32, 45-53.

50. Mauron J (1981) The Maillard reaction in food; a critical review from the nutritional standpoint. Prog Food Nutr Sci 5, 5-35.

51. Naranjo GB, Malec LS \& Vigo M (1998) Reducing sugars effect on available lysine loss of casein by moderate heat treatment. Food Chem 62, 309-313.

52. Brands CMJ, Wedzicha BL \& van Boekel MAJS (2002) Quantification of melanoidin concentration in sugarcasein systems. J Agric Food Chem 50, 1178-1183.

53. Wolf JC, Thompson DR \& Reineccius GA (1977) Initial losses of available lysine in model systems. J Food Sci $\mathbf{4 2}$, $1540-1544$

54. Ajandouz EH, Tchiakpe LS, Ore FD, et al. (2001) Effects of $\mathrm{pH}$ on caramelization and Maillard reaction kinetics in fructose-lysine model systems. I Food Sci $\mathbf{6 6}$, 926-931.

55. Eichner K \& Karel M (1972) The influence of water content and water activity on the sugar-amino browning reaction in model systems under various conditions. J Agric Food Chem 20, 218-223.

56. Faist V \& Erbersdobler HF (2001) Metabolic transit and in vivo effects of melanoidins and precursor compounds deriving from the Maillard reaction. Ann Nutr Metab $\mathbf{4 5}$, $1-12$.

57. van Barneveld RJ (1993) Effect of heating proteins on the digestibility, availability and utilization of lysine by growing pigs $\mathrm{PhD}$ thesis, University of Queensland, Australia

58. Larsen JA, Calvert CC \& Rogers QR (2002) Processing of dietary casein decreases bioavailability of lysine in growing kittens. J Nutr 132, 1748S-1750S

59. Larsen JA, Fascetti AJ, Calvert CC, et al. (2010) Bioavailability of lysine for kittens in overheated casein is underestimated by the rat growth assay method. J Anim Physiol Anim Nutr 94, e102-e108.
60. European Pet Food Industry Federation (2012) Nutritional Guidelines for Complete and Complementary Pet Food for Cats and Dogs. Brussels: FEDIAF.

61. Association of American Feed Control Officials (2011) Official Publication of the Association of American Feed Control Officials. Atlanta, GA: AAFCO Inc.

62. Tran QD, van Lin C, Hendriks WH, et al. (2007) Lysine reactivity and starch gelatinization in extruded and pelleted canine diets. Anim Feed Sci Technol 138, 162-168.

63. Hendriks WH, van Baal J \& Bosch G (2012) Ileal and faecal protein digestibility measurement in humans and other non-ruminants - a comparative species view. $\mathrm{Br} J$ Nutr 108, S247-S257.

64. Hendriks WH, Thomas DG, Bosch G, et al. (2013) Comparison of ileal and total tract nutrient digestibility of dry dog foods. J Anim Sci (In the Press).

65. Hendriks WH \& Sritharan K (2002) Apparent ileal and fecal digestibility of dietary protein is different in dogs. J Nutr 132, 1692S-1694S.

66. Fahey GC, Barry KA \& Swanson KS (2008) Age-related changes in nutrient utilization by companion animals. Annu Rev Nutr 28, 425-445.

67. Hendriks WH \& Emmens M (1998) Apparent ileal nitrogen and amino acid digestibility of a moist cat food. J Nutr 128, 2801S-2801S

68. Rahbar S, Blumenfeld O \& Ranney HM (1969) Studies of an unusual hemoglobin in patients with diabetes mellitus. Biochem Biophys Res Commun 36, 838-843.

69. Henle T (2007) Dietary advanced glycation end products a risk to human health? A call for an interdisciplinary debate. Mol Nutr Food Res 51, 1075-1078.

70. Thorpe SR \& Baynes JW (2003) Maillard reaction products in tissue proteins: new products and new perspectives. Amino Acids 25, 275-281.

71. Somoza V (2005) Five years of research on health risks and benefits of Maillard reaction products: an update. Mol Nutr Food Res 49, 663-672.

72. Luevano-Contreras C \& Chapman-Novakofski K (2010) Dietary advanced glycation end products and aging. Nutrients 2, 1247-1265.

73. Schalkwijk CG, Stehouwer CDA \& van Hinsbergh VWM (2004) Fructose-mediated non-enzymatic glycation: sweet coupling or bad modification. Diabetes Metab Res Rev 20, 369-382.

74. Monnier VM, Bautista O, Kenny D, et al. (1999) Skin collagen glycation, glycoxidation, and crosslinking are lower in subjects with long-term intensive versus conventional therapy of type 1 diabetes: relevance of glycated collagen products versus $\mathrm{HbA1c}$ as markers of diabetic complications. DCCT Skin Collagen Ancillary Study Group. Diabetes Control and Complications Trial. Diabetes 48, 870-880.

75. Vlassara H \& Striker GE (2011) AGE restriction in diabetes mellitus: a paradigm shift. Nat Rev Endocrinol 7, 526-539.

76. Baynes JW (2002) The Maillard hypothesis on aging: time to focus on DNA. Ann N Y Acad Sci 959, 360-367.

77. Turk Z (2001) Glycation and complications of diabetes. Diabetologia Croat 30, 49-54.

78. Chappey O, Dosquet C, Wautier MP, et al. (1997) Advanced glycation end products, oxidant stress and vascular lesions. Eur J Clin Invest 27, 97-108.

79. Singh R, Barden A, Mori T, et al. (2001) Advanced glycation end-products: a review. Diabetologia 44, 129-146.

80. Ramasamy R, Vannucci SJ, Yan SSD, et al. (2005) Advanced glycation end products and RAGE: a common thread in aging, diabetes, neurodegeneration, and inflammation. Glycobiology 15, 16R-28R. 
81. Nass N, Bartling B, Navarrete Santos A, et al. (2007) Advanced glycation end products, diabetes and ageing. $Z$ Gerontol Geriatr 40, 349-356.

82. Basta G, Schmidt AM \& De Caterina R (2004) Advanced glycation end products and vascular inflammation: implications for accelerated atherosclerosis in diabetes. Cardiovasc Res 63, 582-592.

83. Cummings BJ, Head E, Ruehl W, et al. (1996) The canine as an animal model of human aging and dementia. Neurobiol Aging 17, 259-268.

84. Manteca X (2011) Nutrition and behavior in senior dogs. Top Companion Anim Med 26, 33-36.

85. Borras D, Ferrer I \& Pumarola M (1999) Age-related changes in the brain of the dog. Vet Pathol 36, 202-211.

86. Yamka RM, Kitts SE, True AD, et al. (2004) Evaluation of maize gluten meal as a protein source in canine foods. Anim Feed Sci Technol 116, 239-248.

87. Comazzi S, Bertazzolo W, Bonfanti U, et al. (2008) Advanced glycation end products and sorbitol in blood from differently compensated diabetic dogs. Res Vet Sci 84, 341-346.

88. Bras ID, Colitz CMH, Kusewitt DF, et al. (2007) Evaluation of advanced glycation end-products in diabetic and inherited canine cataracts. Graefes Arch Clin Exp Ophthalmol 245, 249-257.

89. Weber K, Schmahl W \& Münch G (1998) Distribution of advanced glycation end products in the cerebellar neurons of dogs. Brain Res 791, 11-17.

90. Shapiro BP, Owan TE, Mohammed SF, et al. (2008) Advanced glycation end products accumulate in vascular smooth muscle and modify vascular but not ventricular properties in elderly hypertensive canines. Circulation 118, 1002-1010.

91. Chiers K, Vandenberge V \& Ducatelle R (2010) Accumulation of advanced glycation end products in canine atherosclerosis. J Comp Pathol 143, 65-69.

92. Sell DR, Lane MA, Johnson WA, et al. (1996) Longevity and the genetic determination of collagen glycoxidation kinetics in mammalian senescence. Proc Natl Acad Sci US A 93, 485-490.

93. Koschinsky T, He CJ, Mitsuhashi T, et al. (1997) Orally absorbed reactive glycation products (glycotoxins): an environmental risk factor in diabetic nephropathy. Proc Natl Acad Sci U S A 94, 6474-6479.

94. Uribarri J, Cai WJ, Sandu O, et al. (2005) Diet-derived advanced glycation end products are major contributors to the body's AGE pool and induce inflammation in healthy subjects. Ann N Y Acad Sci 1043, 461-466.

95. Ames JM (2007) Evidence against dietary advanced glycation endproducts being a risk to human health. Mol Nutr Food Res 51, 1085-1090.

96. Delgado-Andrade C, Tessier F, Niquet-Leridon C, et al. (2012) Study of the urinary and faecal excretion of $N^{\varepsilon}$-carboxymethyllysine in young human volunteers. Amino Acids 43, 595-602.

97. Foerster A \& Henle T (2003) Glycation in food and metabolic transit of dietary AGEs (advanced glycation end-products): studies on the urinary excretion of pyrraline. Biochem Soc Trans 31, 1383-1385.

98. Forster A, Kuhne Y \& Henle T (2005) Studies on absorption and elimination of dietary Maillard reaction products. Ann N Y Acad Sci 1043, 474-481.

99. Godfrey VB, Chen LJ, Griffin RJ, et al. (1999) Distribution and metabolism of (5-hydroxymethyl)furfural in male F344 rats and $\mathrm{B} 6 \mathrm{C} 3 \mathrm{~F} 1$ mice after oral administration. J Toxicol Environ Health A 57, 199-210.
100. Erbersdobler H, Gunsser I \& Weber G (1970) Abbau von Fruktoselysin durch die Darmflora (Degradation of fructose-lysine by the intestinal flora). Zentralbl Veterinarmed A 17, 573-575.

101. Erbersdobler HF \& Faist V (2001) Metabolic transit of Amadori products. Nabrung-Food 45, 177-181.

102. Tuohy KM, Hinton DJS, Davies SJ, et al. (2006) Metabolism of Maillard reaction products by the human gut microbiota - implications for health. Mol Nutr Food Res 50, 847-857.

103. Deppe V, Bongaerts J, O'Connell T, et al. (2011) Enzymatic deglycation of Amadori products in bacteria: mechanisms, occurrence and physiological functions. Appl Microbiol Biotechnol 90, 399-406.

104. Morales F, Somoza V \& Fogliano V (2012) Physiological relevance of dietary melanoidins. Amino Acids $\mathbf{4 2}$ 1097-1109.

105. Birlouez-Aragon I, Saavedra G, Tessier FJ, et al. (2010) A diet based on high-heat-treated foods promotes risk factors for diabetes mellitus and cardiovascular diseases. Am J Clin Nutr 91, 1220-1226.

106. Vlassara H, Cai WJ, Crandall J, et al. (2002) Inflammatory mediators are induced by dietary glycotoxins, a major risk factor for diabetic angiopathy. Proc Natl Acad Sci U S A 99, 15596-15601.

107. Chiang GH (1983) A simple and rapid high-performance liquid chromatographic procedure for determination of furosine, lysine-reducing sugar derivative. I Agric Food Chem 31, 1373-1374.

108. Hewson-Hughes AK, Hewson-Hughes VL, Miller AT, et al. (2011) Geometric analysis of macronutrient selection in the adult domestic cat, Felis catus. J Exp Biol 214, 1039-1051.

109. Hewson-Hughes AK, Hewson-Hughes VL, Colyer A, et al. (2012) Geometric analysis of macronutrient selection in breeds of the domestic dog, Canis lupus familiaris. Behav Ecol 24, 293-304.

110. Elliott K, Rand J, Fleeman L, et al. (2012) A diet lower in digestible carbohydrate results in lower postprandial glucose concentrations compared with a traditional canine diabetes diet and an adult maintenance diet in healthy dogs. Res Vet Sci 93, 288-295.

111. Slingerland L, Fazilova V, Plantinga E, et al. (2009) Indoor confinement and physical inactivity rather than the proportion of dry food are risk factors in the development of feline type 2 diabetes mellitus. Vet J 179, 247-253.

112. Brown RG (1989) Protein in dog foods. Can Vet J 30, $528-531$.

113. Thompson A (2008) Ingredients: where pet food starts. Top Companion Anim Med 23, 127-132.

114. Cramer KR, Greenwood MW, Moritz JS, et al. (2007) Protein quality of various raw and rendered by-product meals commonly incorporated into companion animal diets. J Anim Sci 85, 3285-3293.

115. Young VR \& Pellett PL (1994) Plant-proteins in relation to human protein and amino acid nutrition. Am J Clin Nutr 59, S1203-S1212.

116. ISO (2005) ISO 13903. Animal Feeding Stuffs - Determination of Amino Acid Content. Geneva: ISO.

117. Rokey GJ, Plattner B \& Souza EMd (2010) Feed extrusion process description. $R$ Bras Zootec 39, 510-518.

118. Hand MS, et al (2010) Commercial pet foods. In Small Animal Clinical Nutrition, 5th ed., pp. 156-190 [CD Thatcher, RL Remillard and P Roudebush, editors]. Topeka: Mark Morris Institute.

119. Marsman G (1998) Chemical, physical and nutritional changes in soybean meal as a result of toasting and 
extrusion cooking. PhD Thesis, Wageningen University, The Netherlands

120. Björck I \& Asp NG (1983) The effects of extrusion cooking on nutritional value - a literature review. J Food Eng 2, 281-308.

121. Cheftel JC (1986) Nutritional effects of extrusion-cooking. Food Chem 20, 263-283.

122. Singh S, Gamlath S \& Wakeling L (2007) Nutritional aspects of food extrusion: a review. Int J Food Sci Technol 42, 916-929.

123. Tran QD (2008) Extrusion processing: effects on dry canine diets PhD Thesis, Wageningen University, The Netherlands

124. Eggum BO, Juliano BO, Ibabao MGB, et al. (1986) Effect of extrusion cooking on nutritional-value of rice flour. Food Chem 19, 235-240.

125. Chaiyakul S, Jangchud K, Jangchud A, et al. (2009) Effect of extrusion conditions on physical and chemical properties of high protein glutinous rice-based snack. LWT-Food Sci Technol 42, 781-787.

126. Pham CB \& Delrosario RR (1984) Studies on the develpment of texturized vegetable products by the extrusion process 2. Effects of extrusion variables on the available lysine, total and reducing sugars. J Food Technol 19, 549-559.

127. Lankhorst C, Tran QD, Havenaar R, et al. (2007) The effect of extrusion on the nutritional value of canine diets as assessed by in vitro indicators. Anim Feed Sci Technol $\mathbf{1 3 8}$, 285-297.

128. Adrian J (1974) Nutritional and physiological consequences of the Maillard reaction. World Rev Nutr Diet 19, 71-122.

129. Iwe MO, van Zuilichem DJ, Stolp W, et al. (2004) Effect of extrusion cooking of soy-sweet potato mixtures on available lysine content and browning index of extrudates. J Food Eng 62, 143-150.

130. Mahungu SM, Drozdek KA, Artz WE, et al. (2000) Residence time distribution and barrel fill in pet food twin-screw extrusion cooking. Cereal Chem 77, 220-222.

131. Tran QD, Hendriks WH \& van der Poel AFB (2011) Effects of drying temperature and time of a canine diet extruded with a 4 or $8 \mathrm{~mm}$ die on physical and nutritional quality indicators. Anim Feed Sci Technol 165, 258-264.

132. Nagodawithana TW, Nelles L, Trivedi NB, et al (2010) Protein hydrolysates as hypoallergenic, flavors and palatants for companion animals. In Protein Hydrolysates in Biotechnology, pp. 191-207 [VK Pasupuleti and AL Demain, editors]. Dordrecht: Springer Netherlands.

133. Hendriks WH, Emmens MMA, Trass B, et al. (1999) Heat processing changes the protein quality of canned cat foods as measured with a rat bioassay. J Anim Sci 77, 669-676.
134. Castrillón AM, Navarro MP \& García-Arias MT (1996) Tuna protein nutritional quality changes after canning. J Food Sci 61, 1250-1253.

135. Morken T, Moyano FJ, Márquez L, et al. (2012) Effects of autoclaving and sodium diformate supplementation to diets on amino acid composition, in vivo digestibility in mink (Neovison vison) and in vitro bioavailability using digestive enzymes from Atlantic salmon (Salmo salar). Anim Feed Sci Technol 178, 84-94.

136. Thomas M, van Zuilichem DJ \& van der Poel AFB (1997) Physical quality of pelleted animal feed, 2. Contribution of processes and its conditions. Anim Feed Sci Technol 64, 173-192.

137. Mavromichalis I \& Baker DH (2000) Effects of pelleting and storage of a complex nursery pig diet on lysine bioavailability. J Anim Sci 78, 341-347.

138. Ginste JV \& De Schrijver R (1998) Expansion and pelleting of starter, grower and finisher diets for pigs: effects on nitrogen retention, ileal and total tract digestibility of protein, phosphorus and calcium and in vitro protein quality. Anim Feed Sci Technol 72, 303-314.

139. Delgado-Andrade C, Rufian-Henares JA, Nieto R, et al. (2010) Does the pelleting process affect the nutritive value of a prestarter diet for suckling piglets? Ex vivo studies on mineral absorption. J Sci Food Agric 90, 898-905.

140. Batterham ES, Murison RD \& Lewis CE (1979) Availability of lysine in protein concentrates as determined by the sloperatio assay with growing pigs and rats and by chemical techniques. Br J Nutr 41, 383-391.

141. Morel PCH, Pluske J, Pearson G, et al (1999) A Standard Nutrient Matrix for New Zealand Feedstuffs. Palmerston North: Monogastric Research Centre, Massey University.

142. Batterham ES, Lowe RF, Darnell RE, et al. (1986) Availability of lysine in meat meal, meat and bone meal and blood meal as determined by the slope-ratio assay with growing pigs, rats and chicks and by chemical techniques. Br J Nutr $\mathbf{5 5}$, $427-440$

143. Van Barneveld RJ \& Batterham ES (1994) The effect of heat on amino acids for growing pigs -1 . A comparison of ileal and faecal digestibilities of amino acids in raw and heattreated field peas. Br J Nutr 72, 221-241.

144. Cozannet P, Primot Y, Gady C, et al. (2010) Ileal digestibility of amino acids in wheat distillers dried grains with solubles for pigs. Anim Feed Sci Technol 158, 177-186.

145. CVB (2007) Veevoedertabel, chemische samenstellingen en nutritionele waarden van voedermiddelen (Nutrition Tables, Data on Chemical Compositon and Nutritional Value of Feed Ingredients). Lelystad: Productschap Diervoeder. 